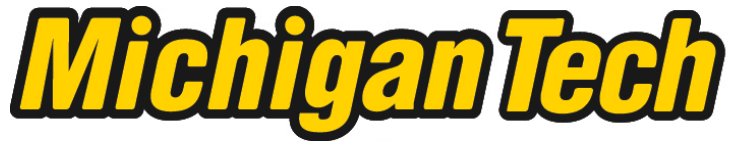 \\ Michigan Technological University Create the Future Digital Commons @ Michigan Tech
}

Is virtuality close enough to reality? A comparison of the effectiveness of simulations with traditional laboratory activities in a high school biology class

Wendelien K. Benya

Michigan Technological University

Follow this and additional works at: https://digitalcommons.mtu.edu/etds

Part of the Science and Mathematics Education Commons

Copyright 2011 Wendelien K. Benya

\section{Recommended Citation}

Benya, Wendelien K., "Is virtuality close enough to reality? A comparison of the effectiveness of simulations with traditional laboratory activities in a high school biology class ", Master's report, Michigan Technological University, 2011.

https://doi.org/10.37099/mtu.dc.etds/534

Follow this and additional works at: https://digitalcommons.mtu.edu/etds

Part of the Science and Mathematics Education Commons 


\title{
IS VIRTUALITY CLOSE ENOUGH TO REALITY? \\ A COMPARISON OF THE EFFECTIVENESS \\ OF SIMULATIONS WITH TRADITIONAL LABORATORY \\ ACTIVITIES IN A HIGH SCHOOL BIOLOGY CLASS
}

\author{
By \\ Wendelien K. Benya
}

\begin{abstract}
A Report
Submitted in partial fulfillment of the Requirements for the degree of

MASTER OF SCIENCE

(Applied Science Education)
\end{abstract}

Michigan Technological University

2011

CWendelien K. Benya 2011 
(This page deliberately blank) 
This thesis, "Is Virtuality Close Enough to Reality? A Comparison of the Effectiveness of Simulations with Traditional Laboratory Activities in a High School Biology Class," is hereby approved in partial fulfillment for the Degree of MASTER OF SCIENCE IN APPLIED SCIENCE EDUCATION.

\section{Department of Cognitive and Learning Sciences}

Signatures:

Thesis Advisor

Dr. Bradley Baltensperger

Committee Member

Dr. Kedmon Hungwe

Committee Member

Dr. Linda Nagel

Department Chair

Dr. Bradley Baltensperger

Date 
(This page deliberately left blank.) 


\section{Table of Contents}

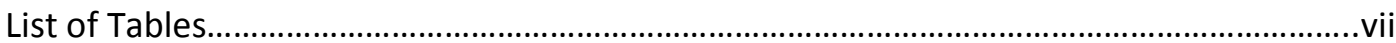

Acknowledgements..............................................................................................................viii

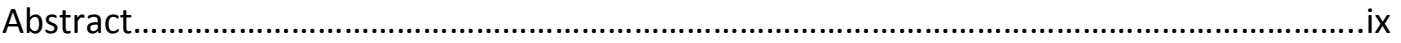

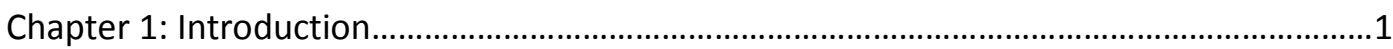

Michigan Science Standards Addressed by this project ........................................... 2

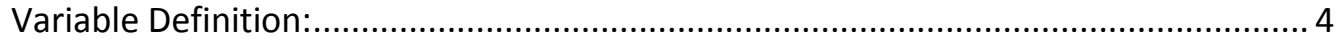

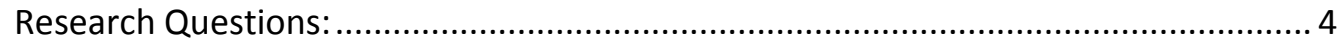

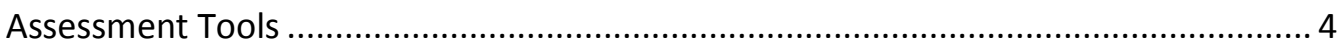

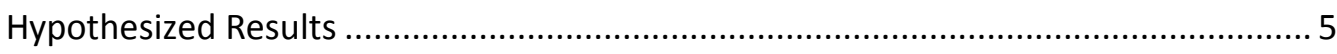

Chapter Two: Literature Review:.....................................................................................

Problems Associated with Wet Lab and Computer Simulations.................................. 8

Benefits Associated with Computer Simulations and Wet Labs ................................ 10

Factors That Improve Student Understanding When Using Simulations...................... 11

Common Misconceptions Regarding Photosynthesis and Respiration......................... 15

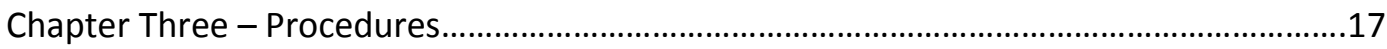

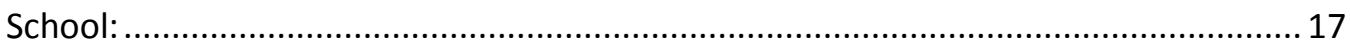

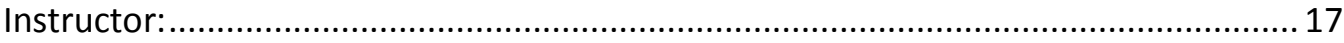

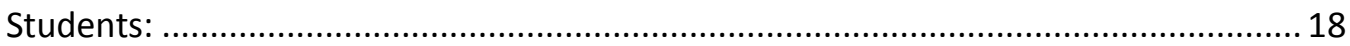

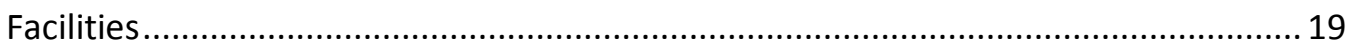

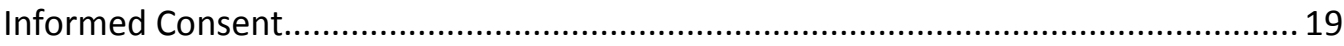

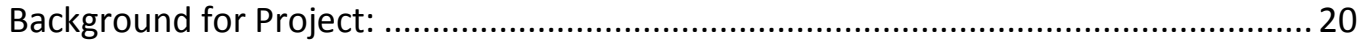

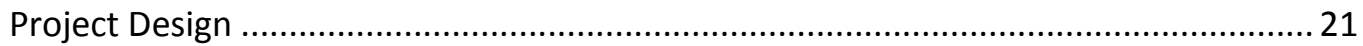

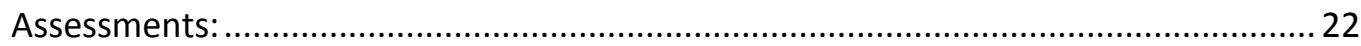

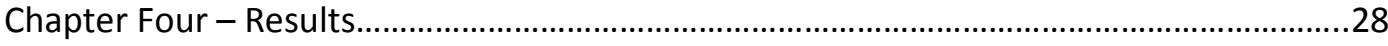

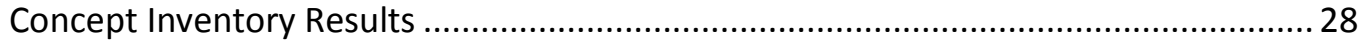

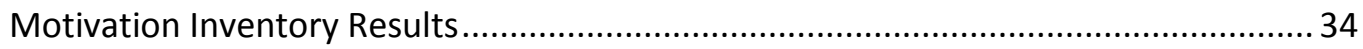

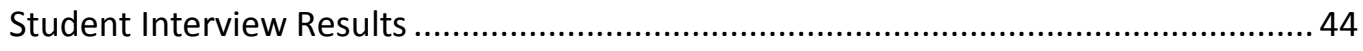

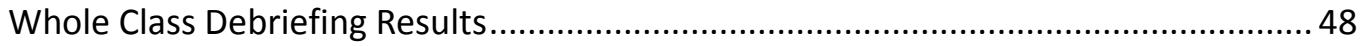




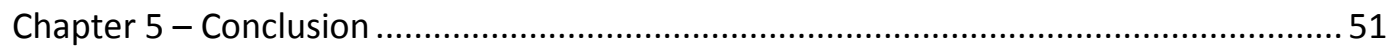

Analysis of Student Results on the Concept Inventory Pre and Post Tests .................. 52

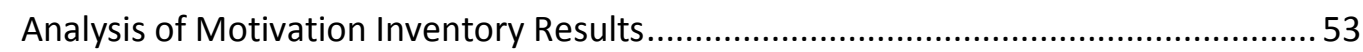

Qualitative Evidence of Student Understanding and Interest .................................... 55

Student Interview Implications \& Class Comparison of Simulations \& Wet Labs.......... 56

Problems, Improvements and Future Studies ......................................................... 57

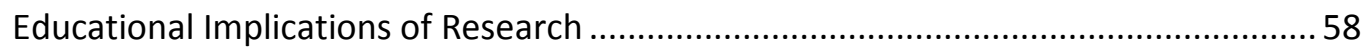

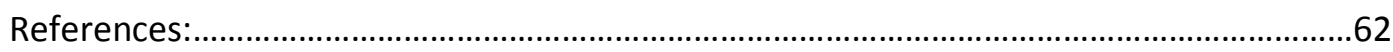

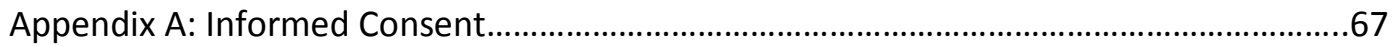

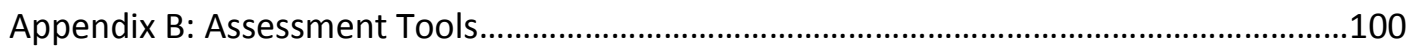

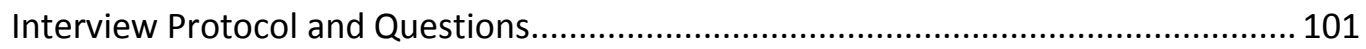

Photosynthesis \& Respiration in Plants Diagnostic Instrument................................... 104

Science Labs Intrinsic Motivation Inventory Pre-Test................................................... 116

Science Labs Intrinsic Motivation Inventory Post-Test ............................................... 120

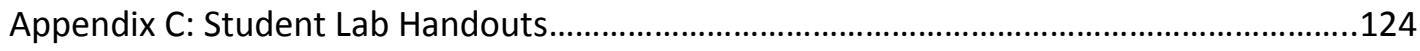

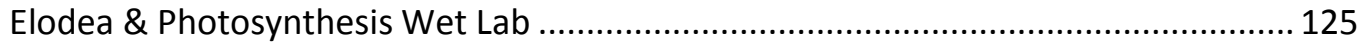

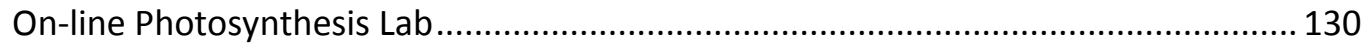

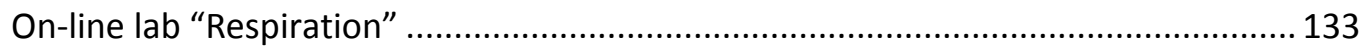

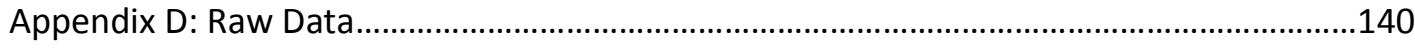

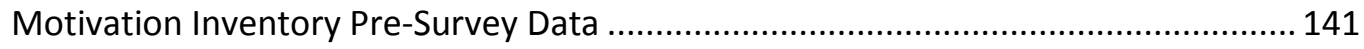

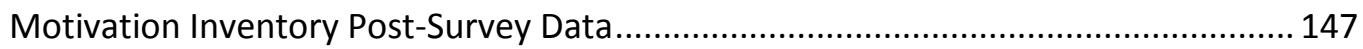




\section{List of Tables}

Table 1. Effect Size Range Correlated to Level of Effectiveness of Intervention or

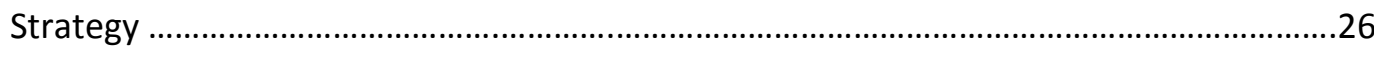

Table 2. Class A Photosynthesis and Cellular Respiration Concept Inventory Pre/Post

Test Knowledge Gain by Item Percent Gain and Effect Size ...............................................30

Table 3. Classes B and C Photosynthesis and Cellular Respiration Concept Inventory Pre/Post Test Knowledge Gain by Item Percent Gain and Effect Size...

Table 4. Comparison of Concept Inventory Pre and Post Test Gain for Items Specifically Testing Photosynthesis Knowledge between Class A and Classes B \& C ...........................32

Table 5. Comparison of Concept Inventory Pre and Post Test Gain for Items Specifically Testing Cell Respiration Knowledge between Class A and Classes B \& C

Table 6. Comparison of Motivation Inventory Pre\& Post Survey Responses for Items Addressing Student Attitude towards Traditional Wet Labs Between Class A and Classes

$B \& C$

Table 7. Comparison of Motivation Post Survey Items addressing Traditional Wet Labs and Virtual Simulations For Their Interest and Enjoyment Factors

Table 8. Comparison of Motivation Post Survey Items addressing Traditional Wet Labs and Virtual Simulations For Their Perceived Competence Factors

Table 9. Comparison of Motivation Post Survey Items addressing Traditional Wet Labs and Virtual Simulations For Their Effort and Importance Factors

Table 10. Comparison of Motivation Post Survey Items addressing Traditional Wet Labs and Virtual Simulations For Their Pressure and Tension Factors

Table 11. Comparison of Motivation Post Survey Items addressing Traditional Wet Labs and Virtual Simulations For Their Value and Usefulness Factors .....

Table 12. Cell Respiration Lab Activity Student Interview Responses

Table 13. Photosynthesis Lab Activity Student Interview Responses

Table 14. Highlights of Student-Developed List of Pros and Cons of Virtual Simulations and Wet Labs 


\section{Acknowledgements}

I would like to thank my students for graciously participating in this study.

Their candid comments and willingness to reflect on their experiences were invaluable to me. I would also like to thank the Early College Alliance administrators, Dave Dugger, Ellen Fischer and Randall Cooper for all of their support during this endeavor. Without their patience, I would not have had the time to complete the work. I would also like to thank the coordinators of the Earth System Science program at Michigan Technological University. They gave me the opportunity to continue with my studies as a member of the initial cohort going through this program. I truly appreciate the opportunity I was given. I especially want to thank my advisor, Dr. Brad Baltensperger, for the time he spent coaching me through the final process. It can be a challenge to work on a project like this without very much face to face time but he gave me the feedback I needed when I need it. Last, I would like to thank my husband Jeff for his support and patience over the last few years. 


\begin{abstract}
Some schools do not have ideal access to laboratory space and supplies. Computer simulations of laboratory activities can be a cost-effective way of presenting experiences to students, but are those simulations as effective at supplementing content concepts? This study compared the use of traditional lab activities illustrating the principles of cell respiration and photosynthesis in an introductory high school biology class with virtual simulations of the same activities. Additionally student results were analyzed to assess if student conceptual understanding was affected by the complexity of the simulation. Although all student groups posted average gain increases between the pre and post-tests coupled with positive effect sizes, students who completed the wet lab version of the activity consistently outperformed the students who completed the virtual simulation of the same activity. There was no significant difference between the use of more or less complex simulations. Students also tended to rate the wet lab experience higher on a motivation and interest inventory.
\end{abstract}





\section{Chapter 1: Introduction}

The purpose of this study is to determine if virtual labs allow students to understand biology concepts as well as, or better than, a real lab experience in a high school science class. I chose this focus for my research because my current access to adequate lab facilities that are conducive to learning is limited. The lab space we are allotted on our campus is cramped, crowded, antiquated and laid out poorly. Students constantly run into each other as they navigate the lab to access equipment and supplies. Student motivation in the laboratory tends to be low. They complain that they cannot see or hear introductory explanations. As a result, they are frequently confused about how to perform the lab work and often make simple mistakes using the lab equipment.

The science department at my school, the Early College Alliance, (ECA) obtained a site license to use virtual, on-line labs provided by eduweblabs.com starting in the fall of 2008. There are two instructors in the biology department and we both currently use the Eduweblabs to replace several of the traditional labs in our curriculum. I had anecdotal evidence from the students that indicated that they prefer the computer simulations and that they learn more from them. However, I had my doubts about their perception of the value of simulations. I wanted to determine if the quantitative and qualitative data would support their claim that they learned more from computer labs or provide evidence for my hypothesis that simulations do not lead to greater gains in understanding compared to the traditional wet lab experience. One other 
consideration that I originally wanted to examine is whether or not students could transfer the lab equipment use skills (reading graduated cylinders, using pipettes, setting up slides in microscopes, etc.) acquired during the on-line experience to the laboratory setting.

\section{Michigan Science Standards Addressed by this project}

During the course of this project, I chose to use the topics of cell respiration and photosynthesis as the framework for the comparison of the effect of virtual labs and traditional wet labs. I picked these topics because I had access to the materials to perform them in the laboratory and the Eduweblab on-line simulations had similar photosynthesis and cell respiration labs. While my primary interest was in the effect of the on-line simulations in promoting conceptual knowledge, I still wanted to make sure that I addressed the Michigan Science Standards (Michigan, Department of, 2006) for those two topics during the unit of instruction. The specific standards addressed were:

○ (LC) III.1 h.1 Explain how multicellular organisms grow, based on how cells grow and reproduce.

○ (LC) III.1 h.2 Compare and contrast ways in which selected cells are specialized to carry out particular life functions.

○ (LO) III.2 m.3 Describe evidence that plants make and store food.

○ (LO) III.2 h.3 Explain the process of food storage and food use in organisms. 
○ (LEC) III.5 m.2 Describe how organisms acquire energy directly or indirectly from sunlight.

$\circ$ (PCM) IV.2 h.1 Explain chemical changes in terms of the breaking of bonds and the rearrangement of atoms to form new substances.

In addition, during the course of the project I reinforced many of the standards covered by the constructing new scientific knowledge and reflecting on scientific knowledge strands. The specific standards (Michigan, Department of, 2006) in those strands that were addressed were:

○ (C) I.1 h.1 Ask questions that can be investigated empirically.

○ (C) I.1 h.2 Design and conduct scientific investigations.

$\circ \quad$ (C) I.1 h.3 Recognize \& explain the limitations of measuring devices.

$\circ$ (C) I.1 h.4 Gather and synthesize information from books and other sources of information. Key concepts: scientific journals, text and computer-based materials

- (R) II.1 h.1 Justify plans or explanations on a theoretical or empirical basis.

- (R) II.1 h.2 Describe some general limitations of scientific knowledge.

○ (R) II.1 h.3 Show how common themes of science, mathematics and technology apply in real world contexts. 


\section{Variable Definition:}

The independent variable in this study is the use of virtual labs of varying complexity to replace the traditional lab experiments using computer simulations instead of actual laboratory equipment and facilities. The dependent variables in this study are the students' conceptual understanding of the lab experiment and the underlying biological principles of cellular respiration and photosynthesis and their motivation and attitude towards lab work.

\section{Research Questions:}

1. Does using Eduweblabs (on-line versions of many traditional lab experiments) lead to greater conceptual understanding compared to a traditional lab experience?

2. Does using a computer simulation like Eduweblabs lead to higher student motivation?

3. Does the level of complexity of a lab experience affect the gain in student conceptual understanding and, if so, do simulations reflect the same differences?

\section{Assessment Tools}

I quantitatively assessed the dependent variables using a variety of methods. The students' conceptual understanding of the topics of cellular respiration and photosynthesis were assessed using the photosynthesis and respiration in plants concept inventory developed by Haslam and Treagust (1987) as a pre and post-test. Student motivation was assessed using a modified version 
of the intrinsic motivation inventory (IMI) developed by Deci and Ryan (2005) as a pre and post-test. I used one simple or one complex simulation for each treatment group and compared their results on the concept pre and post tests as well as the results of their motivation inventories.

The dependent variables were additionally assessed in several qualitative forms. I interviewed a small sample of students after completing either the wet lab or the virtual simulation using a slightly modified interview protocol developed by Winberg, Anders and Berg (2007). The interview covered student understanding, motivation and ability to apply their understanding to a new situation. I also took notes on student behavior during each lab or simulation and interviewed each class at the end of both lab experiences to gauge student reaction.

\section{Hypothesized Results}

Based on my preliminary observations of students completing virtual labs and anecdotal evidence, I hypothesize that the data I collect will address my research questions as follows. In response to my first research question regarding conceptual understanding, I predict that the computer simulation group will have a lower gain in understanding than students who perform the same activity in a traditional lab environment. I base this hypothesis on the student behavior and peer dialogue I observed in the computer lab in the year prior to conducting this formal investigation. Students appeared to be pushing buttons and trying to get to the next part of the lab as if it were a video game instead of a simulation designed to illustrate biological concepts. Student dialogue during those sessions primarily 
seemed to be limited to discussions on how to navigate through a "room" with little discussion or questions about the concepts illustrated by the activity.

My second research question deals with student motivation. Based on student comments from last year, I do think that students will feel more motivated to complete lab work in a computer lab and rate the simulation experience higher than the wet lab experience. Last year students told me they preferred the computer lab to the traditional lab because it was less time consuming, less messy and easier to go back and correct if they made mistakes (which the eduweblab website allows them to do).

My last research question examines the role of the level of complexity in the simulation at promoting conceptual understanding. Based on my prior experience, I think students will gain a better conceptual understanding of underlying biological principles if the simulations are less complex. When they are more complex, students spend more time on following directions and less on determining why they are doing the particular activity in the first place. While complex wet labs are also more challenging for students to comprehend, they have more time during the experience to ask for clarification since most of these types of labs incorporate a time period to wait for results.

\section{Possible Effect of the Research}

If my hypothesis is incorrect and the virtual labs are as effective at supplementing classroom instruction and illustrating main concepts, then I would recommend to my school administrators to devote more resources to obtaining site licenses and software to supplement our curriculum. Computer simulations 
have the advantage to be cheaper than equipping an entire lab. They are much more portable and they do not consume materials that must be replaced for every new cohort of students. However, if my hypothesis is correct and wet labs promote greater conceptual understanding, I will continue to utilize them in my instruction. This may require greater creativity and flexibility but the extra time, effort and financial outlay will be worth it if students develop a deeper understanding of content by performing a hands-on wet lab. 


\section{Chapter Two: Literature Review:}

De Jong and van Joolingen (1998) found a mixture of study results that compared student learning using computer-based instruction simulations (CBIS) with traditionally expository, teacher-driven instruction. Some studies showed students learned more using CBIS, some showed students learned less and some showed no difference between the two methods. Since the studies they analyzed had such mixed results, they examined the study results further to see if there were common factors that contributed to more or less student success.

\section{Problems Associated with Wet Lab and Computer Simulations}

Instructors need to be very clear on the reasons they are incorporating a lab into their curriculum in the first place regardless of whether it is a wet lab or dry simulation. Kirschner and Huisman (1998) argue that most labs are a waste of time and resources. They do not give the educational return on the amount of time and money invested into them. Labs often only serve to verify something that the student already knows. They are often fool-proof which gives students a false sense of the nature of science and leaves them with the impression that labs

always have one right answer and go smoothly. In cases where students are asked to solve real problems, they are overwhelmed and easily give up. Kirschner and Huisman (1998) emphasize that students need a good conceptual framework prior to performing a lab so they can meaningfully interpret observations. Concept 
formation can be enhanced by a lab experience but learners need to be exposed to a concept multiple times before it is embedded into their body of understanding.

Triona and Klahr (2003) hypothesized that students who used computer simulations to learn concepts would be unable to transfer that understanding to the design of actual experiments using physical manipulatives. They found little difference between students who had originally used the computer simulation and those that used physical manipulatives. However, they suggested that further work needs to be done to see how computer use affects cognitive development of concepts since this approach is still fairly new.

Größler (2004) brings up several important considerations regarding the use of simulators in education. First, the simulation is only as valid as the designer. The designer's knowledge, experience, world view and understanding of educational practices will all shape how valuable the simulation can be. The designer decides whether time will be compressed or expanded, what options a user will be presented with, and the level of complexity embedded within the simulation; all of these will shape the end experience for the user. Additionally, he points out that for many students the virtual simulation presents no risk and therefore is more apt to be viewed as a task to be completed as quickly as possible. Therefore, it behooves the designer to borrow some ideas from the gaming world to increase the appeal and level of interest in the work, which can be quite challenging to do. 


\section{Benefits Associated with Computer Simulations and Wet Labs}

What are some of the benefits and advantages associated with computer based simulations? De Jong and van Joolingen (1998) found that virtual simulations fostered discovery learning by allowing students to determine the characteristics of the principles underlying the simulation through trial and error. Several studies point out the value of using simulations in situations where the classroom teacher does not have access to laboratory equipment due to space, cost, time, portability or safety issues (Kirschner \& Huisman, 1998; Triona \& Klahr, 2004; Zumbach, Schmitt, Reimann \& Starkloff, 2006; Wekesa, Kiboss \& Ndirangu, 2006; Blake \& Scanlon, 2007). Several of these authors worked in economically challenged environments where virtual access was better than no access. Another benefit discussed in several of the studies was the motivational factor associated with computer simulations. Some topics like cell division are usually presented with very static lab activities using preserved specimens that do not give students a good conceptual understanding of what they are observing (Wekesa, Kiboss \& Ndirangu, 2006). An interactive computer simulation model allows students to "see" the microscopic workings of a cell and gain a better intuitive understanding of what is happening.

While there are many advantages associated with the use of simulations in the classroom, wet labs can provide some skills that are lacking in many simulations. For example, wet labs allow students to practice and refine their use of laboratory equipment and procedures that cannot be wholly duplicated by a simulation (Winberg \& Berg, 2007). According to Hofstein \& Lunetta (2004), the wet lab environment gives students the opportunity to work cooperatively and 
problem solve when confronted with equipment failures or design flaws. They suggest that this is such an important component of the laboratory experience that students should be assessed on their ability to problem solve in addition to the intended lab outcomes. Marbach-Ad et. al (2009) conducted a study of integrating the use of simulations with wet labs, multi-media and small group discussions to promote interest in microbiology for non-majors. They chose this multi-faceted approach to not only increase conceptual understanding but also to promote the problem-solving, collaborative nature of science. While time consuming, the participants in the study showed gains on concept assessments but also articulated a better understanding of the process of science in interviews, discussions and open-ended responses.

\section{Factors That Improve Student Understanding When Using Simulations}

Most of the studies attempted to find key factors that improved student comprehension and conceptual understanding when using a simulation to replace the traditional lab experience. Several common themes emerged from these studies. Students who use computer based simulations that have embedded scaffolding almost always outperformed students on tests of definitional knowledge (Swaak, van Jooligen \& de Jong, 1998). Definitional knowledge was considered to be knowledge of conceptual elements. Embedded scaffolding took many forms. The types of extra support that were found to be most beneficial were guided practice, model progression and explanation of specific domain 
knowledge (Schauble, Glaser, Duschl, Schulz \& John, 1995; de Jong \& van

Joolingen, 1998; Swaak, van Joolingen \& de Jong, 1998; Brush \& Saye, 2001).

Guided practice questions embedded in the simulation allowed students to process and internalize the concepts. Model progression refers to the idea of starting the simulation with a very simple model with one or two variables that have clearly visible effects and gradually increasing the complexity when the learner has attained the level of prior knowledge necessary to be successful in more complex situations. Since not all students enter with the same level of prior knowledge, having domain specific explanations embedded within the program that were accessible on demand also led to increased success particularly in lower performing or unmotivated students. However, there is a caveat to providing students with domain specific knowledge. The knowledge must be accessible to the student during the simulation when the student needs it for it to have an impact. Studies where the students were given supplemental information before the lab showed no gains in learning but when on-demand supports were embedded within the simulation students demonstrated significant gains in learning (Blake \& Scanlon, 2007; Brush \& Saye, 2001).

Blake and Scanlon (2007) also found that student success depended on teacher mediation and student familiarity with technology. Students who did not receive any extra feedback from teachers did still make gains in definitional knowledge acquisition but fared very poorly in intuitive and propositional knowledge gains. Since a simulation is a model of real world events that allows students to manipulate and observe the results (Blake \& Scanlon, 2007) learners should be able to not only understand the conceptual elements, but they also 
should be able to predict outcomes when variables are changed (intuitive knowledge) and understand the relationships between the variables (propositional knowledge). In her work with middle-schoolers, Schauble (1995) found that very few of the students understood the purpose of the experiments they performed, they could not identify the relevant variables nor could they relate the experiment to a real life situation. Blake and Scanlon (2007) reported similar findings with undergraduate students who had no support or discussion before, during or after the computer simulation experiences. Clearly student success depends on the instructor helping students to debrief and reflect on the meaning of the simulation experience.

Hattie (2009, p. 230-1) analyzed seven studies regarding the efficacy of using simulations in the classroom. Based on these, he found that simulations worked better for high school and college-level students. Interventions that lasted a week or less were more effective at promoting concept mastery than programs that lasted longer than a week. Low-level students were often helped by simulations more than higher-level students. Simulations that supported or confirmed classroom concepts were more effective than replacing traditional teaching completely with a simulation.

Suprasorn et. al. (2008) found that using simulations in a chemistry class as a pre-lab exercise helped students form a mental model of what was happening in the microscopic world that they could use as a framework to explain the macroscopic observations during a traditional laboratory exercise. Their study started from the premise that simulations are valuable but then compared the effect of embedding audio narration to on-demand text support into the simulation 
to see which had the greatest effect on student gain in conceptual knowledge. Their results showed that students who interacted with simulations that had a text component instead of an audio narration performed better on conceptual tests. The eduweb labs in their current format do have a text component rather than an audio component which allows students to review material on an as-needed basis.

Last, little research involving simulations discussed whether or not students could transfer the lab equipment skills from the virtual environment to an actual laboratory setting. The reason I am curious about this is because Eduweblabs put a great emphasis on familiarizing students with lab equipment. The programs allow students to make mistakes like breaking glassware, accidentally releasing newly hatched fruit flies or not turning equipment on.

Blake \& Scanlon (2007) found that students did not acquire new skills in any of the three computer simulations students participated in. However, Finkelstein et. al. (2005) found that under certain conditions, virtual simulations could teach transferrable lab skills. They used a computer simulation to replace a direct current laboratory unit and found students who were exposed to the simulations were able to correctly solve new circuit construction problems approximately $20 \%$ faster than student who had only been exposed to a hands-on lab. The simulation students also scored on average $8 \%$ higher on a concept inventory. The authors suggested that the simulation students performed better on both types of assessments because the simulations allowed them to "mess around" and observe what happened when they changed component factors. 


\section{Common Misconceptions Regarding Photosynthesis and Respiration}

In choosing to target the concepts of photosynthesis and respiration during the course of this comparison of computer simulations and wet labs, I first needed to identify common misconceptions that students have regarding these topics.

Several studies examining misconceptions held by high school students found that the same misconceptions persisted in college students including those who were entering into secondary biology education majors (Haslam \& Treagust, 1987; Russell, Netherwood \& Robinson, 2004).

Hershey (2004) broke misconceptions regarding plants into five main categories: oversimplifications, overgeneralizations, obsolete concepts and terms, misidentifications and flawed research. Oversimplification and overgeneralization tend to be the source of most of the misconceptions regarding photosynthesis and cell respiration. Canal (1999) found that the pattern of misconception formation begins in primary school, is built upon in secondary school and often carries over into post-secondary studies.

Some of the main misconceptions the studies consistently identified were students' belief that plants use the soil for the majority of their food and cannot grow without soil. They also believe that plants only photosynthesize and animals are the only organisms that respire. Hershey's concept of oversimplification (2004) is often exemplified by students' persistent belief in Canal's concept of 'inverse respiration' which is the idea that photosynthesis is the reverse of respiration and is, in fact, the plant version of respiration (Amir \& Tamior, 1994; Canal, 1999). Students tend to think that photosynthesis is a onestep process that only occurs in plants and directly produces glucose and oxygen. 
Many students also believe that plants do not use oxygen. More advanced

students will acknowledge that plants do respire but often think this only happens at night when there is no light available for photosynthesis (Haslam \& Treagust, 1987; Russell, Netherwood \& Robinson, 2004). 


\section{Chapter Three - Procedures}

\section{School:}

The Early College Alliance (ECA) is a public early college program on the campus of Eastern Michigan University. The ECA is a Washtenaw County public school consortium in partnership with seven local school districts. The ECA district partners are Ann Arbor Public Schools, Chelsea Community Schools, Lincoln Consolidated Schools, Milan Area Schools, Whitmore Lake Public Schools, Willow Run Community Schools and Ypsilanti Public Schools. The program is currently in its $4^{\text {th }}$ year of operation with 360 students enrolled.

Students may apply to our program during their ninth or tenth grade year and begin our program at the start of either their tenth or eleventh grade. Each district is allowed a quota of slots based on the size of their district and the space available. Thirty percent of the slots are reserved for students on free or reduced lunch which qualifies us as a Title I school. Students must complete a comprehensive application packet, write an application essay and complete a battery of entrance exams. However, admission is on a lottery basis and does not reflect how well a student performs on the entrance exams.

\section{Instructor:}

I was the only instructor participating in this study. Originally one of my colleagues was going to participate as a control group but unfortunately had to take a medical leave of absence for the term. I have been certified by the state of 
Michigan to teach biology since 1997 and have actively taught biology classes for over 5 years. The cell respiration and photosynthesis unit was presented over thirteen days from November $3^{\text {rd }}$ to November $19^{\text {th }}$ of 2010.

\section{Students:}

There were a total of 72 students enrolled in my three sections of Survey of Science in the fall of 2010. There were 41 males and 31 females total at the outset of the study. During the course of the project 3 students left before completing the post-test. The male to female ratio was approximately $1: 1$ for 2 of the classes. The third class had twice as many males as females. The ethnic makeup of the students was $76.4 \%$ Caucasian, $19.4 \%$ African-American and $4.2 \%$ Asian. Each class had approximately the same ethnic makeup. The academic abilities of the students varied greatly within each class but had similar variation between classes. In the first semester of our program, we monitor and evaluate the academic progress and potential of each student in each subject area. Students that are deemed academically ready are moved into college classes after one semester of ECA classes. This means there is a much wider ability level in our first semester courses than in our second semester courses. One thing that most students have in common, regardless of their ability level, is more academic motivation than the peers that remain in their high school districts since they had to make a conscious effort to apply to our program. 


\section{Facilities}

All class lectures were conducted in Roosevelt Hall on the Eastern Michigan University campus. Lab classes were held in our facilities in Sill Hall for the traditional wet labs and in computer labs located in Halle Library for the on-line simulations. Class sizes ranged from 23 to 26 students. Students worked in groups of 3 in the wet lab due to equipment limitations but this did allow them to collaborate and discuss the investigation as they were completing it. Each student had access to a computer for the on-line simulations. While all of the computers were located in the same lab, there was much less collaboration among students during the simulations. Class periods lasted for 80 minutes.

\section{Informed Consent}

Students were informed about participating in a research project at the beginning of the semester. All students and parents were given informed consent forms along with a description of the project (Appendix A). No individual data or names were used in the data analysis. Survey and test data were only analyzed for class results and trends. Interview responses were coded by classroom treatment and no names were included for student confidentiality. Once research was completed, all personal information that was collected during the project was destroyed. The research protocol was approved by the Michigan Technological University Institutional Review Board (M0632). 


\section{Background for Project:}

I have used five on-line versions of laboratory experiments in previous semesters combined with five traditional experiments in the laboratory. I found that students responded well to the less complex simulations but had a much more difficult time constructing meaning from the more complex simulations. For example, one of the first on-line versions I used was a general biology photosynthesis experiment that asked students to evaluate the effect of temperature and distance from a light source on the rate of photosynthesis. Each variable was examined individually and had very clear results. In general, most students could find the relationships between variables and explain what happened in the simulation and why. More recently, I used the AP Biology version of population genetics. Students could easily perform the immediate task at hand during the experiment of counting genotypes of beetles. However, when asked to relate this to Hardy-Weinberg equilibrium predictions, very few could translate beetle genotypes into equilibrium observations. I realized that I had not adequately prepared students to analyze the data and the on-line lab does not offer extensive embedded scaffolding to support student needs during the simulation. These observations coupled with the compelling evidence in my literature review detailing the need for adequate supports for students using simulations made me rethink the plan for my research project and the need to embed more support throughout the entire project. 


\section{Project Design}

I used my intact classrooms to participate in the different treatments for my research questions. I taught 3 sections of ECA science during the fall of 2010. Students were randomly assigned to my classes. Class A had 26 students and Classes B \& C each had 23 students. Based on wet lab and computer lab availabilities, I assigned Class A to do the more complex cell respiration lab as a wet lab while Classes B \& C completed the same lab as a computer simulation. For the simpler photosynthesis lab, I had Classes B \& C complete it as a wet lab while Class A performed it on-line.

Both experiments illustrated some fairly basic main concepts regarding photosynthesis or cell respiration. The photosynthesis experiment tracked the relationship between the rate of oxygen production and the distance a plant is from its light source. The concept students should have seen illustrated is that the rate of oxygen production and therefore photosynthesis increases when the plant is closer to the light. The cell respiration experiment compared the rate of oxygen consumption between germinated and non-germinated peas. The cell respiration concept students should have seen illustrated is that cells that are actively growing like germinating peas use much more oxygen and therefore undergo more aerobic cell respiration than cells that are quiescent.

I ascribed the terms complex or simple to each of the experiments based on several factors that affected how easy or difficult the experiment was to perform and then analyze. The virtual photosynthesis experiment was quick to set up and usually took less than half an hour for students to complete. The traditional photosynthesis wet lab was also relatively easy to set up and usually 
took students no more than 45 minutes to set up, collect data and clean up. The traditional cell respiration wet lab required much longer to set up and meticulous attention to detail was required in order for it to be successful. Students typically took a little longer than their 80 minute class period to complete this, especially if they made any mistakes in their set-up and had to start over. By contrast, the virtual cell respiration lab was much quicker to complete, with most students finishing in approximately 30 minutes. Time was compressed so students did not have to wait 20 "real" minutes to collect data. Additionally if students made a mistake, as the program did allow, it was merely a matter of redoing a few mouse clicks to correct the error and move on.

Regardless of which style of lab students performed, we spent the day following the lab debriefing what they had done. We discussed what happened and attempted to explain why, using the concepts of photosynthesis and cell respiration. I explained how to calculate the change in volume of oxygen for the cell respiration lab to students who had a difficult time understanding how to use the formula.

\section{Assessments:}

Student achievement was measured using a mix of formal quantitative and informal qualitative assessments. All students took the same concept inventory on respiration and photosynthesis (Appendix B; Haslam \& Treagust, 1987) as a pre and post-test to assess improvements in knowledge of the concepts. This concept inventory contains 13 items in a multiple choice format. However, in 
order for students to show understanding of the underlying concepts, they had to choose the correct justification for their response. The reason choices included distractors that had been identified by prior research as sources of misconceptions. Amir and Tamir (1994) found similar results for a concept test they developed that also required students to justify their responses to items.

For each of the labs, four students were interviewed following the protocol developed by Winberg, Anders and Berg (2007). I asked two students from each treatment to answer the survey questions. In each case, I interviewed one higher level student and one lower level student to assess the reactions of different ability levels. I interviewed a total of 8 students. After both labs were completed, there was a debriefing session and whole class discussion on the relative merits and flaws associated with both wet and dry labs. This whole class format allowed me to verify whether or not the responses from the interviewed students were typical.

All students took an intrinsic motivation survey based on Deci and Ryan's (2005) survey. The pre and post-test (Appendix B) were slightly different. The pre-test only asked about attitudes towards labs in general while the post-test differentiated between traditional wet labs and computer simulations. The original inventory included questions covering seven factors the researchers found relevant to the students' subjective experience related to lab activities. I chose not to include items from the "perceived choice" and "relatedness" factors. Since all of the students were required to participate in the lab activity as part of the class requirements, they did not have much choice about whether or not they would participate. The relatedness factor items all asked students to assess their feelings 
towards their lab partner. The questions were more geared to labs that assigned permanent lab partners which was not the case in this instance. I included items from the following categories: interest/enjoyment, perceived competence, effort/importance, pressure/tension and value/usefulness.

\section{Analysis}

The average gain in student knowledge was assessed by finding the difference between the mean class post-test and the mean class pre-test. The formula for calculating the average gain in student knowledge is

$$
\text { Average Item Gain }=\bar{X}_{\text {class post-test }}-\bar{X}_{\text {class pre-test }}
$$

The following example shows the average item gain in student knowledge for students who completed the less complex virtual simulation. (Table 2)

Average Item Gain $=57.69 \%-48.52 \%$

Average Item Gain $=9.17 \%$

The effectiveness of the interventions was determined by using the effect size. Effect size is calculated dividing the average gain by the standard deviation of the control group. (Coe, 2002; Hattie 2009) The formula used to find effect size is 
Effect size $=\left[\bar{X}_{\text {experimental }}-\overline{\mathrm{X}}_{\text {control }}\right] / \mathrm{SD}_{\text {control }}$

In this case, I considered the pre-test student results to be the control group and used the post-test results as the experimental group. Calculating effect size allows me to estimate not only whether or not the intervention (more or less complex virtual simulations) was effective as a tool for enhancing concept acquisition but also allows me to rank how effective the intervention was at promoting concept mastery.

According to Hattie (2009), almost any intervention has an effect on learning outcomes and quite often a positive but perhaps negligible effect. He argues that whether or not an intervention is effective is the wrong question to ask. Instead, it is much more important to evaluate how well something works compared to other possible interventions. After evaluating over 800 different studies and comparing the relative effects, he developed a general barometer to assess the importance of various effect sizes. I measured the effectiveness of using simple or complex virtual simulations to replace traditional wet labs using the barometer he developed. Using his scale, effect sizes can be interpreted as follows: 


\section{Table 1. Effect Size Range Correlated to Level of Effectiveness of Intervention or Strategy *}

\begin{tabular}{cl}
\hline Effect Size Range & \multicolumn{1}{c}{ Interpretation } \\
\hline$-0.2-0$ & $\begin{array}{l}\text { Negative Effect: The intervention had a negative } \\
\text { effect on concept mastery. }\end{array}$ \\
$0-0.1$ & $\begin{array}{l}\text { Low Effect: These are the effects you would } \\
\text { expect solely attributable to aging and maturing. }\end{array}$ \\
& $\begin{array}{l}\text { Medium Effect: Typical effects of a teacher } \\
\text { during the course of instruction }\end{array}$ \\
$>0.1-0.4$ & $\begin{array}{l}\text { High Effect: Effects which are attributable to the } \\
\text { specific intervention or method used in the } \\
\text { classroom }\end{array}$ \\
\hline * Based on Hattie, 2009, p. 19
\end{tabular}

Negative effects are obviously undesirable and indicate that the intervention actually causes a decline in student achievement. The low effect range of effect sizes is based on the yearly increase in student achievement based on age alone. Hattie (2009) based this range on comparisons with children in countries that had no access to schooling or were only exposed to very limited amounts of in-school education. While this range is the typical gain that a child may achieve over a year and this research project only took place over a few weeks, it may still be a good indicator as a low end of effectiveness for a particular topic like photosynthesis or cell respiration.

After evaluating over 800 meta-analyses of studies related to student achievement, Hattie (2009) found that most interventions fall into the medium effect range. This means students are progressing and that teachers are 
facilitating learning in their classroom environments. He also cautions that just because an intervention may only demonstrate an effect size in the medium range, does not necessarily mean that it is without value. Some of the interventions that had the highest effect sizes were also very time-consuming and expensive to implement. In some cases, the additive properties of multiple, lower effect size, interventions and strategies were actually more effective overall and realistic to implement. Obviously, any interventions that lead to effect sizes in the high effect range are the most desirable. These correspond to strategies that improve student understanding between half a grade level to a full grade level or beyond (Coe 2002; Hattie, 2009). 


\title{
Chapter Four - Results
}

\section{Concept Inventory Results}

\begin{abstract}
All students were required to take the photosynthesis and cellular respiration concept inventory as a pre and post test (Appendix B). The pre and post-tests were identical. The pre-test was administered on 11/3/2011 and was not returned to the students. In order for an answer to be considered correct, students must have chosen the right answer along with the correct reason to explain that answer. Students were informed of the number of responses they had that included both the correct answer and the correct reason but did not see the test again until the post-test was administered on 11/19/2011.

All class average scores increased between the pre and the post-test (Tables 2 and 3). The average gain increase for Class A, the class who performed the simple virtual simulation, was $9.17 \%$. This was fairly similar to the average gain of $10.14 \%$ demonstrated by Classes B \& C who performed the more complex virtual simulation. However, Class A had a post-test percentage of $57.69 \%$ which was actually higher than Classes B \& C who had a mean post-test score of $50.45 \%$ even though they did not have the higher average gain.

This discrepancy may be the result of Classes B and C scoring significantly lower on the pre-test compared to Class A. Classes B and C had an average score of $40.30 \%$ on the pre-test compared to the $48.52 \%$ pre-test average posted by Class A. This discrepancy between the two treatments gave Classes B and $\mathrm{C}$ more opportunity for improvement on the post-test. Another possible
\end{abstract}


explanation for the performance discrepancy may be that more students were enrolled in Classes B and C (46 students) than were enrolled in Class A (26 students). Classes B \& C had more variation in them since they had more students overall so there was a better chance for students in those classes to have had less previous exposure to biology concepts which could adversely affect their pretest scores. Additionally Classes B and C lost 3 students during the course of the study. One student moved, one student dropped the class and the third student returned to her home district. The loss of these three post-test scores may also have slightly impacted the results.

When the concept inventory questions were broken down by items that specifically tested the individual concepts of photosynthesis or cellular respiration, the results were more skewed. In Class A, the class which performed the simple virtual photosynthesis lab, the class average gain was only $5.45 \%$ on concept inventory items addressing photosynthesis compared to a $9.70 \%$ average gain posted by Classes B \& C who performed the photosynthesis wet lab (Table 4). Conversely, the average gain for the classes which performed the cell respiration wet lab was $11.56 \%$ compared to the $7.60 \%$ gain posted by the class which completed the virtual cell respiration lab (Table 5). 
Table 2. Class $A^{*}$ Photosynthesis and Cellular Respiration Concept Inventory Pre/Post Test Knowledge Gain by Item Percent Gain and Effect Size

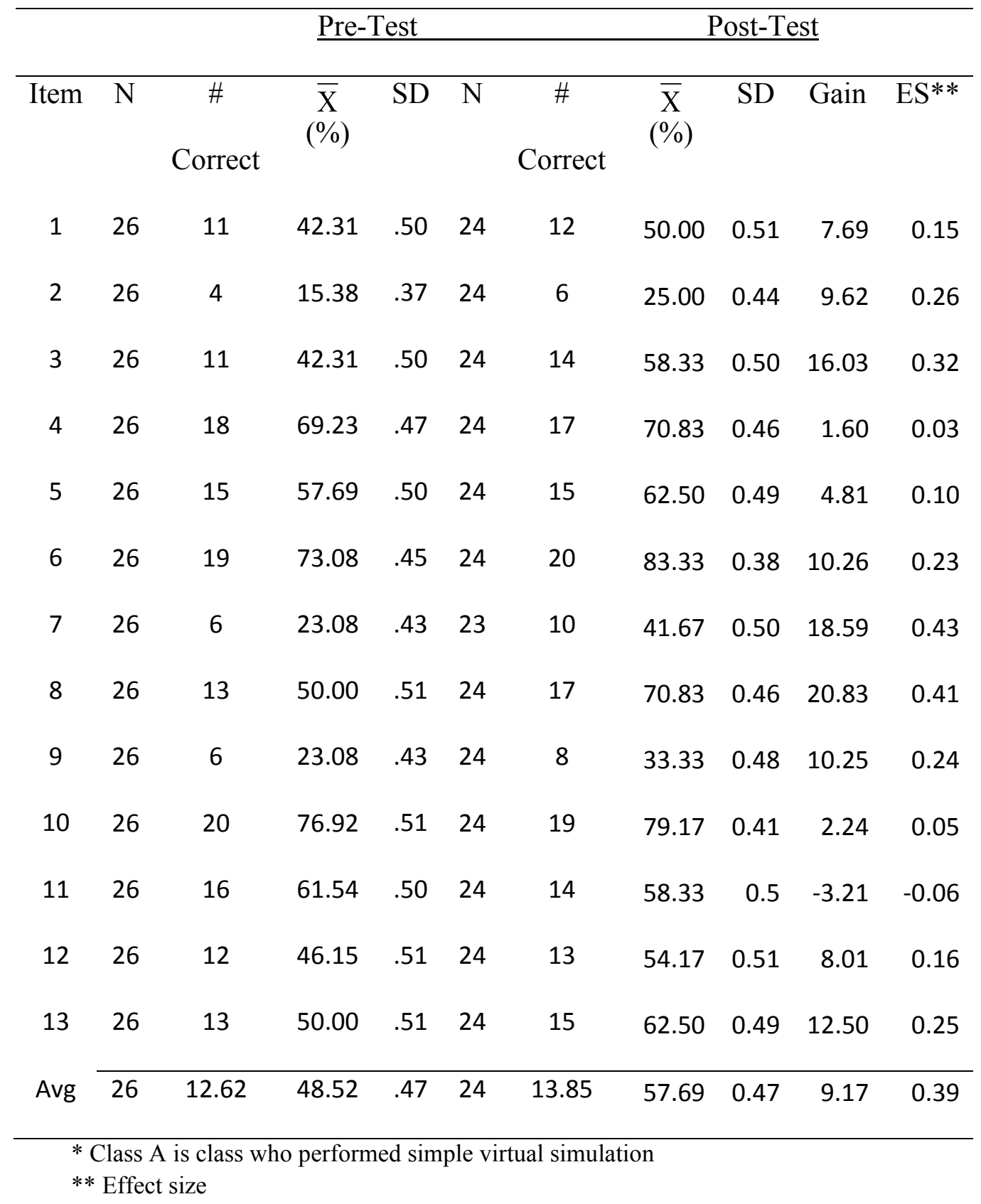


Table 3. Classes B and C* Photosynthesis and Cellular Respiration Concept Inventory Pre/Post Test Knowledge Gain by Item Percent Gain and Effect Size

Pre-Test Post-Test

\begin{tabular}{|c|c|c|c|c|c|c|c|c|c|c|}
\hline Item & $\mathrm{N}$ & $\begin{array}{c}\# \\
\text { Correct }\end{array}$ & $\mathrm{X}_{(\%)}$ & SD & $\mathrm{N}$ & $\begin{array}{c}\# \\
\text { Correct }\end{array}$ & $\begin{array}{c}\bar{X} \\
(\%)\end{array}$ & $\overline{S D}$ & Gain & ES** \\
\hline 1 & 46 & 11 & 23.91 & 0.43 & 43 & 13 & 30.23 & 0.46 & 6.32 & 0.15 \\
\hline 2 & 46 & 4 & 8.70 & 0.28 & 43 & 14 & 32.56 & 0.47 & 23.86 & 0.85 \\
\hline 3 & 46 & 12 & 26.09 & 0.44 & 43 & 29 & 67.44 & 0.47 & 41.35 & 0.94 \\
\hline 4 & 46 & 38 & 82.61 & 0.38 & 43 & 38 & 88.37 & 0.32 & 5.76 & 0.15 \\
\hline 5 & 46 & 25 & 54.35 & 0.50 & 43 & 17 & 39.53 & 0.49 & -14.82 & -0.30 \\
\hline 6 & 46 & 35 & 76.09 & 0.43 & 43 & 35 & 81.40 & 0.39 & 5.31 & 0.12 \\
\hline 7 & 46 & 4 & 8.70 & 0.28 & 43 & 9 & 20.93 & 0.41 & 12.23 & 0.44 \\
\hline 8 & 46 & 22 & 47.83 & 0.51 & 43 & 22 & 51.16 & 0.51 & 3.33 & 0.07 \\
\hline 9 & 46 & 4 & 8.70 & 0.28 & 43 & 7 & 16.28 & 0.37 & 7.58 & 0.27 \\
\hline 10 & 46 & 32 & 69.57 & 0.47 & 43 & 27 & 62.79 & 0.49 & -6.78 & -0.14 \\
\hline 11 & 46 & 26 & 56.52 & 0.50 & 43 & 28 & 65.12 & 0.48 & 8.60 & 0.17 \\
\hline 12 & 46 & 14 & 30.43 & 0.47 & 43 & 21 & 48.84 & 0.51 & 18.41 & 0.39 \\
\hline 13 & 46 & 14 & 30.43 & 0.47 & 43 & 22 & 51.16 & 0.51 & 20.73 & 0.44 \\
\hline Avg & 46 & 19 & 40.30 & 0.42 & 43 & 22 & 50.45 & 0.45 & 10.14 & 0.52 \\
\hline
\end{tabular}


Table 4. Comparison of Concept Inventory Pre and Post Test Gain for

Items Specifically Testing Photosynthesis Knowledge

between Class $A^{\star}$ and Classes $B$ and $C^{* *}$

\begin{tabular}{|c|c|c|c|c|}
\hline Item \# & $\begin{array}{c}\text { Class A Pre- } \\
\text { Test \% } \\
\text { Correct }\end{array}$ & $\begin{array}{c}\text { Class A Post- } \\
\text { Test } \% \\
\text { Correct }\end{array}$ & $\begin{array}{c}\text { Classes B \& } \\
\text { C Pre-Test \% } \\
\text { Correct }\end{array}$ & $\begin{array}{c}\text { Classes B \& } \\
\text { C Post-Test } \\
\% \text { Correct }\end{array}$ \\
\hline 1 & 42.31 & 50.00 & 23.91 & 30.23 \\
\hline 10 & 76.92 & 79.17 & 69.57 & 62.79 \\
\hline 11 & 61.54 & 58.33 & 56.52 & 65.12 \\
\hline 12 & 46.15 & 54.17 & 30.43 & 48.84 \\
\hline 13 & 50.00 & 62.50 & 30.43 & 52.38 \\
\hline Mean & 55.38 & 60.83 & 42.17 & 51.87 \\
\hline SD & 14.03 & 11.26 & 19.78 & 13.90 \\
\hline Avg Gain & & 5.45 & & 9.70 \\
\hline Avg Effect & & 0.39 & & 0.49 \\
\hline Size & & & & \\
\hline
\end{tabular}


Table 5. Comparison of Concept Inventory Pre and Post Test Gain for Items Specifically Testing Cell Respiration Knowledge between Class $A^{*}$ and Classes $B$ and $C^{* *}$

\begin{tabular}{|c|c|c|c|c|}
\hline Item \# & $\begin{array}{c}\text { Class A Pre- } \\
\text { Test \% } \\
\text { Correct }\end{array}$ & $\begin{array}{c}\text { Class A Post- } \\
\text { Test } \% \\
\text { Correct }\end{array}$ & $\begin{array}{c}\text { Classes B \& } \\
\text { C Pre-Test \% } \\
\text { Correct }\end{array}$ & $\begin{array}{c}\text { Classes B \& } \\
\text { C Post-Test } \\
\% \text { Correct }\end{array}$ \\
\hline 2 & 15.38 & 25.00 & 9.09 & 32.56 \\
\hline 3 & 42.31 & 58.33 & 26.09 & 44.19 \\
\hline 4 & 69.23 & 70.83 & 82.61 & 88.37 \\
\hline 5 & 57.69 & 62.50 & 54.35 & 39.53 \\
\hline 6 & 73.08 & 83.33 & 76.09 & 81.40 \\
\hline 7 & 23.08 & 43.48 & 8.70 & 20.93 \\
\hline 8 & 50.00 & 70.83 & 47.83 & 51.16 \\
\hline 9 & 23.08 & 32.00 & 8.89 & 16.28 \\
\hline Mean & 44.23 & 55.79 & 39.21 & 46.80 \\
\hline SD & 22.05 & 20.45 & 30.42 & 26.21 \\
\hline Avg Gain & & 11.56 & & 7.60 \\
\hline $\begin{array}{l}\text { Avg Effect } \\
\text { Size }\end{array}$ & & 0.52 & & 0.25 \\
\hline
\end{tabular}


While both treatments posted noticeable average gains between the pre and post-test, there were a few individual items that declined between the pre and post-test. The most dramatic drop between the pre and post-test results occurred for item 5. This question asked students to identify where cell respiration occurred in plants and why. The classes that performed the virtual cell respiration declined by $-14.82 \%$ with a negative effect size of -0.30 (Table 3 ). On the other hand, the class that performed the cell respiration wet lab posted a gain of $4.81 \%$ with a positive effect size of 0.10 (Table 2) for the same item. This result seems to indicate that performing the wet lab helped students grasp the concept of the ubiquitous nature of cell respiration in living things. However, before I put too much credence in this correlation, I must also acknowledge that the class that performed the photosynthesis wet lab posted a negative gain on item 10 (Table 3 ) which required students to identify the overall summary of equation for photosynthesis and give the reason why it is the correct equation.

\section{Motivation Inventory Results}

Students completed the motivation inventory pre-test (Appendix B) on 11/5/2010 at the beginning of the unit on photosynthesis and cell respiration. At that point in the semester, they had worked in the lab on several activities and experiments but had not completed any virtual simulations. Initially lab activities were guided with specific procedures but as the term progressed, students began developing and implementing their own investigations on prescribed topics with instructor guidance and feedback. For almost a third of the students, this was their first experience in a lab-based class. They took the motivation inventory 
post-test on 12/8/2010 after they had completed the unit on photosynthesis and cell respiration and gotten all assessments returned to them with feedback.

Because of time constraints, the post-test contained the same number of items but was slightly modified to give students an opportunity to differentiate between traditional wet labs and virtual simulations.

Table 6 shows the comparison of the motivation pre-survey and postsurvey results for items only addressing student attitude towards traditional wet labs. The response scale ranged from 1 , which corresponded to "not at all true" response, to the survey statement to 7, which corresponded to "very true". Both classes began with a very similar mean response towards traditional labs. Class A had a 5.20 mean response to the pre-survey items while Classes B \& C posted a 5.22 mean response to the same statements. The post-survey shows that both groups slightly adjusted their responses downward with a post mean response of 4.82 for Class A, the class that completed the more complex wet lab and a post mean response of 5.10 for classes B \& $\mathrm{C}$ which completed the same complex lab in a virtual simulation.

The composite mean Likert-type scale response may have dropped between the pre and post motivation survey due to the topics for the gas exchange unit. Photosynthesis and cell respiration are fairly abstract topics that are difficult to visualize for students and they are made even more difficult to comprehend by the plant background most students bring to class. Typically students in primary schools are introduced to plant morphology and respiration early on with little explanation. As a result, they think that plants breathe just like animals and rarely give the topic more advanced thought (Amir, R. and Tamir, P., 1994). Earlier 
topics for lab investigations in the fall 2010 science classes covered more dynamic, concrete topics that involved open-ended investigations illustrating topics like water properties, osmosis and the differences between lipids and carbohydrates with more noticeable results. The photosynthesis and cell respiration labs required more patience and concentration than previous work and thus may have been perceived as less enjoyable. 
Table 6. Comparison of Motivation Inventory Pre and Post Survey Responses for Items Addressing Student Attitude towards Traditional Wet Labs Between Class A and Classes B \& C

\begin{tabular}{|c|c|c|c|c|c|c|c|c|}
\hline & \multicolumn{2}{|c|}{ Class $\mathrm{A}^{*}$} & \multicolumn{3}{|c|}{ Classes B \& C** } & \multirow[b]{2}{*}{$\begin{array}{l}\text { post } \\
\text { mean }\end{array}$} & \multirow[b]{2}{*}{ Pre SD } & \multirow[b]{2}{*}{ ES } \\
\hline Survey Statement**** & $\begin{array}{c}\text { pre } \\
\text { mean }\end{array}$ & $\begin{array}{l}\text { post } \\
\text { mean }\end{array}$ & Pre SD & ES & $\begin{array}{c}\text { pre } \\
\text { mean }\end{array}$ & & & \\
\hline $\begin{array}{l}\text { I enjoy doing lab activities and } \\
\text { experiments. }\end{array}$ & 5.36 & 4.76 & 2.61 & -0.23 & 5.60 & 5.12 & 4.11 & -0.12 \\
\hline $\begin{array}{c}\text { Even if I do not do well } \\
\text { working on a lab at first, I } \\
\text { usually feel competent by the } \\
\text { time we are finished. }\end{array}$ & 5.12 & 4.80 & 2.92 & -0.11 & 5.07 & 5.05 & 2.85 & -0.01 \\
\hline I put a lot of effort into labs. & 5.48 & 5.44 & 2.56 & -0.02 & 5.64 & 5.50 & 2.46 & -0.06 \\
\hline I do not feel nervous doing labs. & 2.56 & 4.64 & 3.62 & 0.57 & 1.90 & 5.57 & 2.84 & 1.29 \\
\hline $\begin{array}{l}\text { I believe doing labs and } \\
\text { experiments could be of some } \\
\text { value to me in this class. }\end{array}$ & 6.04 & 5.52 & 2.16 & -0.24 & 6.14 & 5.67 & 2.86 & -0.17 \\
\hline Labs are boring. & 5.83 & 2.48 & 3.43 & -0.98 & 5.87 & 2.80 & 2.79 & -1.10 \\
\hline I feel skilled working in the lab. & 4.83 & 4.30 & 2.18 & -0.24 & 4.64 & 4.79 & 2.85 & 0.05 \\
\hline $\begin{array}{l}\text { I try hard on labs and } \\
\text { experiments. }\end{array}$ & 5.82 & 6.00 & 2.02 & 0.09 & 5.67 & 5.70 & 2.44 & 0.01 \\
\hline I feel relaxed doing labs. & 5.00 & 4.48 & 2.87 & -0.18 & 5.62 & 5.08 & 3.09 & -0.17 \\
\hline $\begin{array}{l}\text { I think doing lab activities and } \\
\text { experiments is important } \\
\text { because it can teach me new } \\
\text { skills. }\end{array}$ & 5.95 & 5.73 & 1.95 & -0.11 & 6.05 & 5.70 & 2.93 & -0.12 \\
\hline Mean Response & 5.20 & 4.82 & 2.63 & -0.15 & 5.22 & 5.10 & 2.92 & -0.04 \\
\hline
\end{tabular}


In the initial pre-test motivation inventory, there were 4 questions corresponding to each factor of motivation based on Deci and Ryan's (2005) inventory template. Those factors included interest/enjoyment, perceived competence, effort/importance, pressure/tension and value/usefulness. In the post-test, I modified two of the four questions in each category to specifically apply to the virtual lab experience.

Table 7 shows the results for the interest/enjoyment component of motivation. In general, both treatments (Class A: simple virtual experience and Classes B \& C: complex virtual experience) rated the traditional wet lab higher and therefore more enjoyable and interesting than completing labs on-line. However, the standard deviation in their responses is quite high so there was not a general consensus on how interesting or enjoyable the activities were.

Students did not differentiate greatly between the level of competence they felt completing labs on-line or in the traditional lab (Table 8). The results for these questions had a much lower standard deviation than all of the other categories. Students found virtual simulations and traditional labs almost equivalent in their perception of how much effort they had to invest and how important it was for them to do well on the lab assignment (Table 9). Neither treatment rated virtual labs or traditional labs as significant sources of pressure or tension (Table 10). A rating of seven on the pressure/tension questions indicated a high amount of pressure or tension while a rating of 1 indicated no pressure or tension. Both classes had means between 3 and 4 in this category. However, Classes B \& C (complex virtual simulation) rated both lab experiences as slightly higher sources of pressure and tension than Class A. Both treatments rated both 
lab styles the highest on the survey for their value and usefulness with all class means reported between 5 and 6 on the 7 point scale (Table 11).

Table 7. Comparison of Motivation Post Survey Items addressing Traditional Wet Labs and Virtual Simulations For Their Interest and Enjoyment Factors

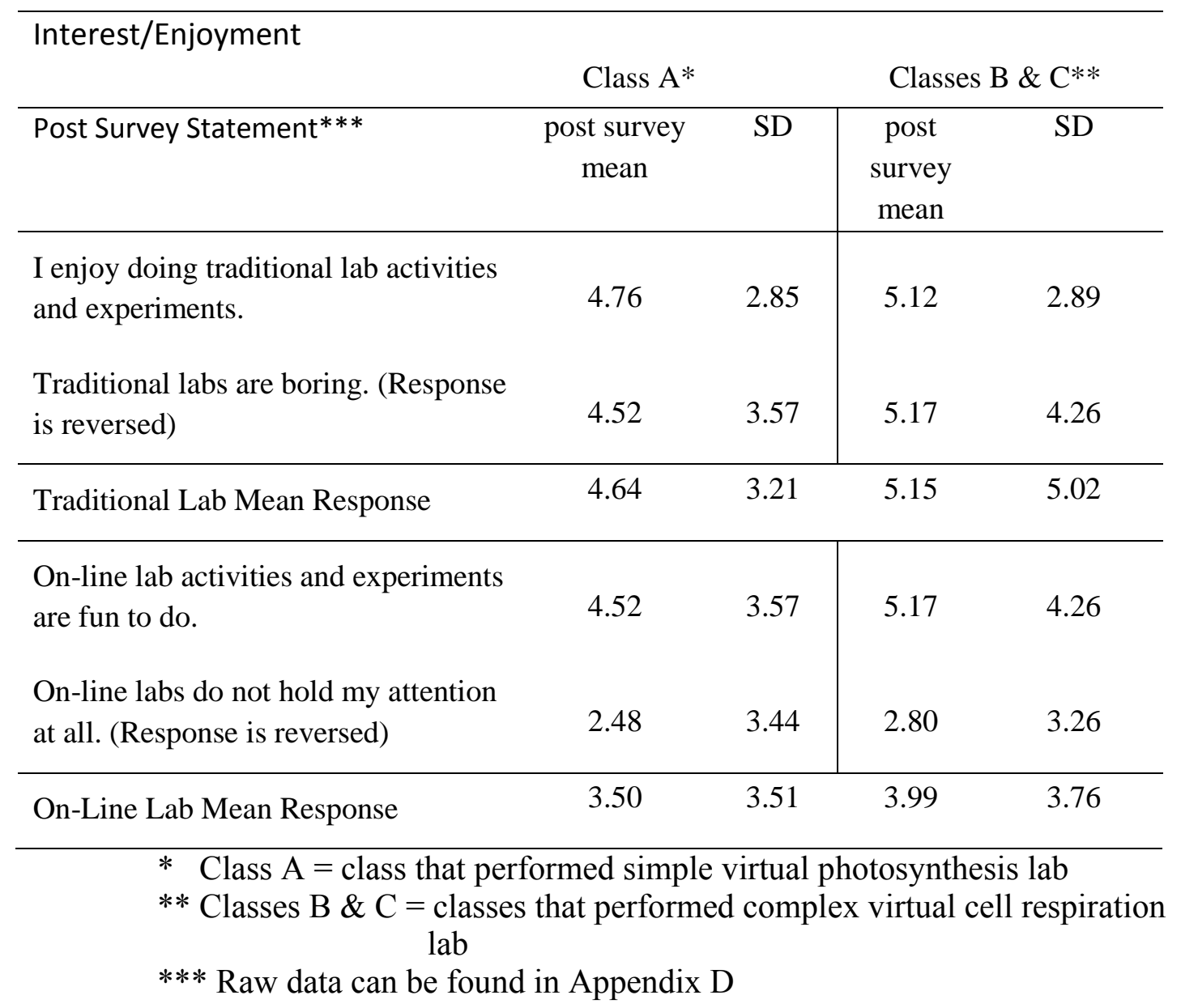


Table 8. Comparison of Motivation Post Survey Items addressing Traditional Wet Labs and Virtual Simulations For Their Perceived Competence Factors

\begin{tabular}{|c|c|c|c|c|}
\hline \multirow{2}{*}{$\begin{array}{l}\text { Perceived Competence } \\
\text { Post Survey Statement*** }\end{array}$} & \multicolumn{2}{|l|}{ Class A* } & \multicolumn{2}{|c|}{ Classes B \& $\mathrm{C}^{* *}$} \\
\hline & $\begin{array}{l}\text { post survey } \\
\text { mean }\end{array}$ & $\mathrm{SD}$ & $\begin{array}{c}\text { post } \\
\text { survey } \\
\text { mean }\end{array}$ & SD \\
\hline $\begin{array}{l}\text { Even if I do not do well working on a } \\
\text { traditional lab at first, I usually feel } \\
\text { competent by the time we are } \\
\text { finished. }\end{array}$ & 4.80 & 2.59 & 5.05 & 2.63 \\
\hline I feel skilled working in the lab. & 5.00 & 2.89 & 5.29 & 2.97 \\
\hline Traditional Lab Mean Response & 4.90 & 2.74 & 5.17 & 2.80 \\
\hline $\begin{array}{l}\text { I am satisfied with how I work on on- } \\
\text { line labs and experiments. }\end{array}$ & 5.00 & 2.89 & 5.29 & 2.97 \\
\hline $\begin{array}{l}\text { In general, I do not do well working } \\
\text { on on-line labs. (Response is } \\
\text { reversed.) }\end{array}$ & 4.30 & 2.19 & 4.79 & 2.50 \\
\hline On-Line Lab Mean Response & 4.65 & 2.54 & 5.04 & 2.74 \\
\hline $\begin{array}{l}* \text { Class } \mathrm{A}=\text { class that perfo } \\
* * \text { Classes B \& } \mathrm{C}=\text { classes } \mathrm{t} \\
\text { lab } \\
* * * \text { Raw data can be found i1 }\end{array}$ & $\begin{array}{l}\text { ted simple } v \\
\text { t performed } \\
\text { Appendix D }\end{array}$ & $\begin{array}{l}\text { ual p } \\
\text { mple }\end{array}$ & $\begin{array}{l}\text { tual ce } \\
\text { tual ce }\end{array}$ & piration \\
\hline
\end{tabular}


Table 9. Comparison of Motivation Post Survey Items addressing

Traditional Wet Labs and Virtual Simulations For Their

\section{Effort and Importance Factors}

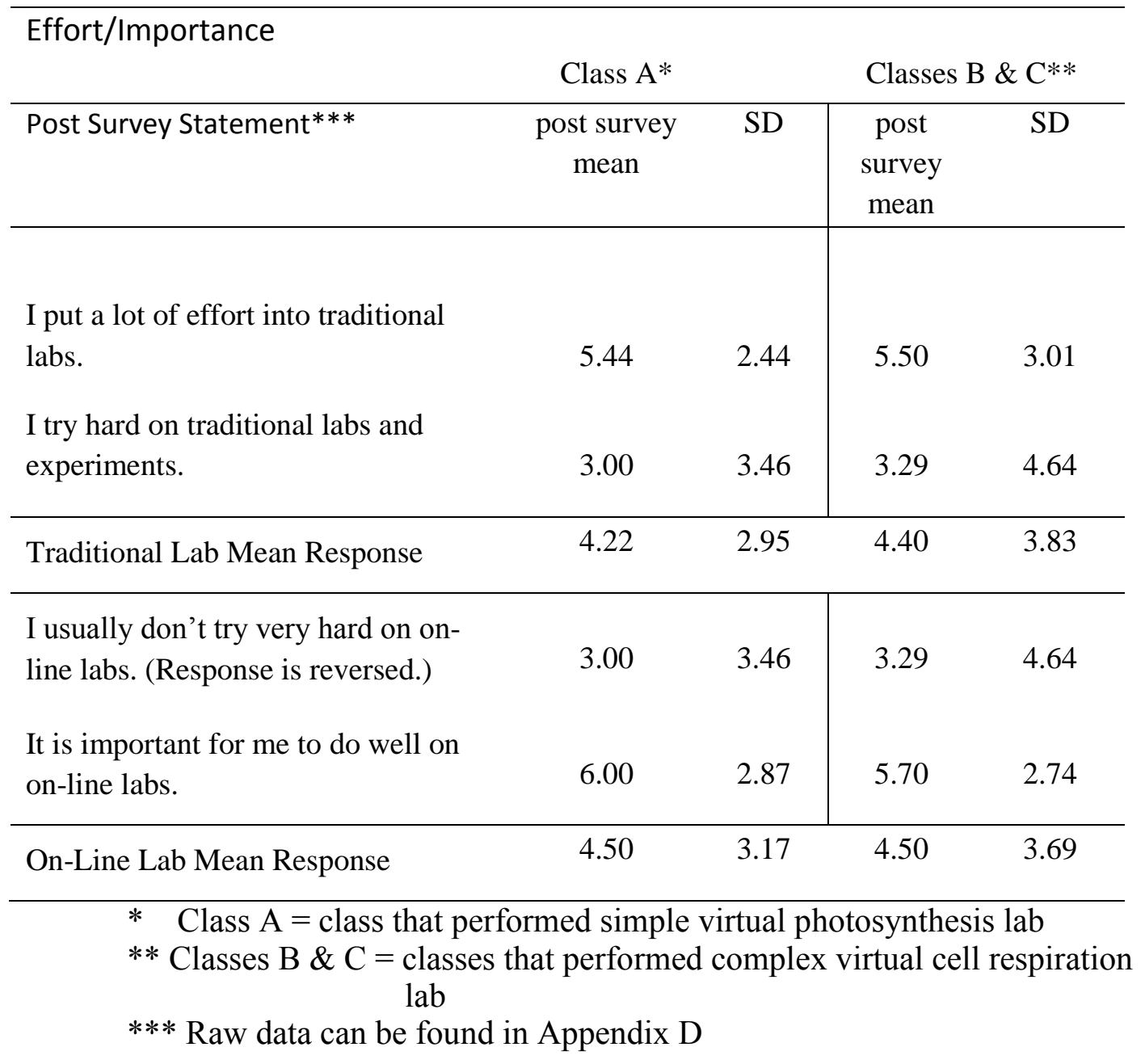


Table 10. Comparison of Motivation Post Survey Items addressing

Traditional Wet Labs and Virtual Simulations For Their

Pressure and Tension Factors

\begin{tabular}{|c|c|c|c|c|}
\hline \multicolumn{5}{|l|}{ Pressure/Tension } \\
\hline & \multicolumn{2}{|l|}{ Class A* } & \multicolumn{2}{|c|}{ Classes B \& $\mathrm{C}^{* *}$} \\
\hline Post Survey Statement*** & $\begin{array}{l}\text { post survey } \\
\text { mean }\end{array}$ & SD & $\begin{array}{c}\text { post } \\
\text { survey } \\
\text { mean }\end{array}$ & SD \\
\hline $\begin{array}{l}\text { I do not feel nervous doing traditional } \\
\text { labs. (Response is reversed.) }\end{array}$ & 4.64 & 3.30 & 5.57 & 3.93 \\
\hline $\begin{array}{l}\text { I feel relaxed doing traditional labs. } \\
\text { (Response is reversed.) }\end{array}$ & 2.00 & 2.18 & 2.31 & 4.85 \\
\hline Traditional Lab Mean Response & 3.32 & 2.74 & 3.94 & 4.39 \\
\hline $\begin{array}{l}\text { I feel tense when doing on-line lab } \\
\text { activities. }\end{array}$ & 2.00 & 2.18 & 2.31 & 4.85 \\
\hline $\begin{array}{l}\text { I feel anxious when I work on on-line } \\
\text { lab activities or experiments. }\end{array}$ & 4.48 & 3.72 & 5.08 & 3.06 \\
\hline On-Line Lab Mean Response & 3.23 & 2.95 & 3.70 & 3.96 \\
\hline
\end{tabular}

* Class $\mathrm{A}=$ class that performed simple virtual photosynthesis lab

** Classes $\mathrm{B} \& \mathrm{C}=$ classes that performed complex virtual cell respiration lab

*** Raw data can be found in Appendix D 


\section{Table 11. Comparison of Motivation Post Survey Items addressing Traditional Wet Labs and Virtual Simulations For Their Value and Usefulness Factors}

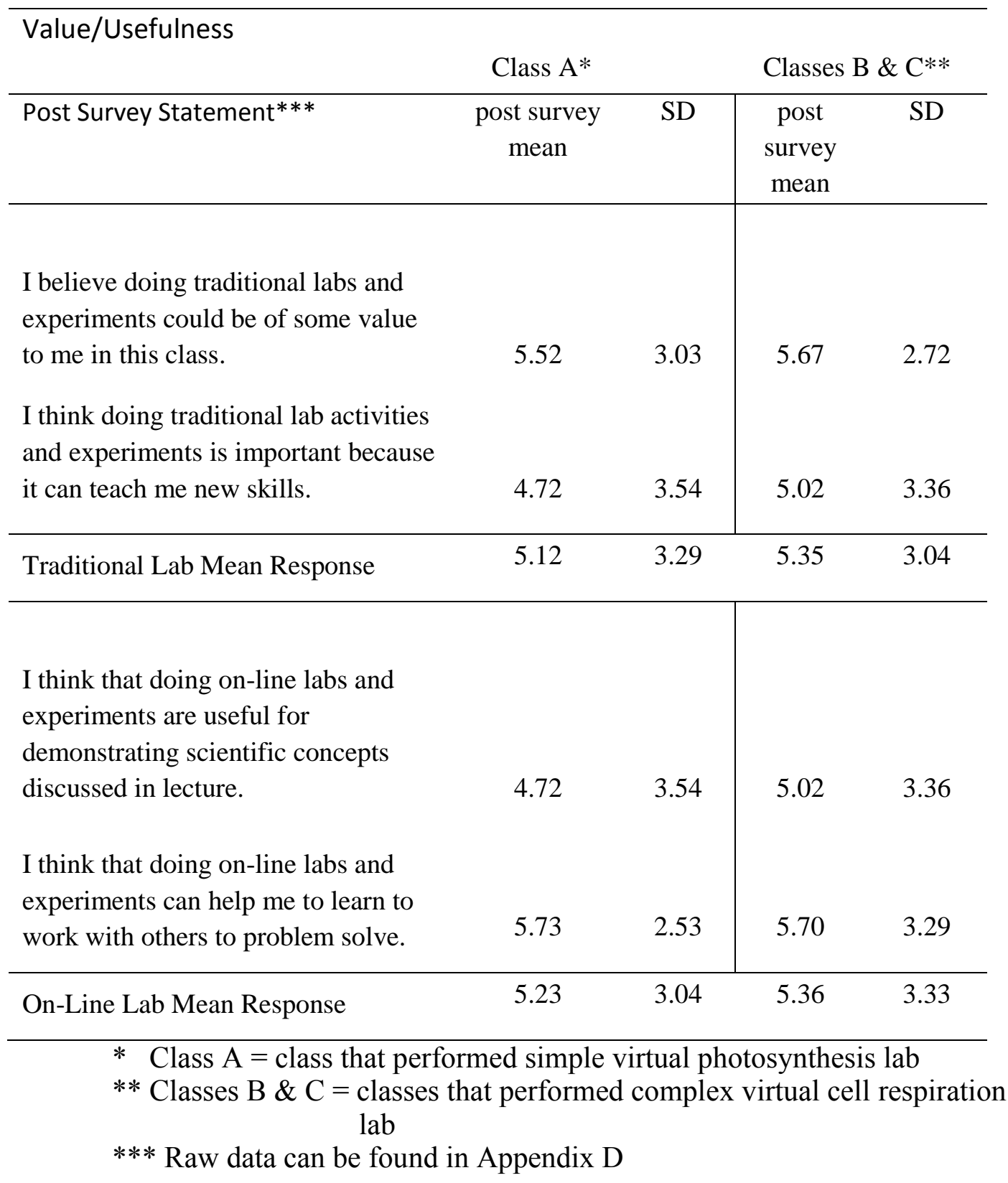




\section{Student Interview Results}

I not only administered concept and motivation inventories to all students in my classes, I also interviewed a small sample of students after each lab experience following a modified interview protocol (Appendix B) created by Winberg, Anders and Berg (2007). Cell respiration was the first topic in the gas exchange unit that included photosynthesis and cell respiration. The cell respiration lab was completed as a wet lab by Class A and as a virtual lab by Classes B and C on 11/9/2010. Both classes were debriefed on 11/10/2010. During the debriefing, we went over calculations, discussed what happened, analyzed flaws and reviewed the main concepts of cell respiration. The wet lab was time consuming and complex and did not allow much room for error.

Interviews were conducted with students privately on 11/12/2010. I chose 1 high level and 1 low level student to interview from each treatment. I defined high level students as students who were receiving an A or a B in class, actively participated in class discussions and consistently asked questions to clarify concepts or probe for more in-depth understanding. I defined low level students as students who had a C- or lower in the class, were often chatty and off topic and did not actively participate in class discussions. I included their responses to four of the questions on the interview protocol (Appendix D) in their own words. 
Table 12. Cell Respiration Lab Activity Student Interview Responses

\begin{tabular}{|c|c|c|c|c|}
\hline \multirow[b]{2}{*}{$\begin{array}{l}\text { Interview } \\
\text { Question }\end{array}$} & \multicolumn{2}{|c|}{ Virtual Cell Respiration Lab(complex simulation) } & \multicolumn{2}{|c|}{ Traditional Cell Respiration Wet Lab } \\
\hline & Student A - low level & $\begin{array}{c}\text { Student B - high } \\
\text { level }\end{array}$ & Student A - low level & $\begin{array}{c}\text { Student B - high } \\
\text { level }\end{array}$ \\
\hline $\begin{array}{l}\text { Describe } \\
\text { what you } \\
\text { did } \\
\text { during } \\
\text { this lab. }\end{array}$ & $\begin{array}{l}1^{\text {st }} \text { put on goggles (found } \\
\text { this funny). Had to take } \\
\text { peas and fill beaker, add } \\
\text { beads to make them even } \\
\text { and then put the long thing } \\
\text { in them and cotton balls } \\
\text { and drops and it measures } \\
\text { respiration in peas and } \\
\text { beads while we timed with } \\
\text { a stopwatch }\end{array}$ & $\begin{array}{l}\text { Create equal volumes } \\
\text { to match by adding } \\
\text { beads. Placed basket } \\
\text { over beaker to remove } \\
\text { water. Built a } \\
\text { respirometer with } \\
\text { cotton, nonabsorbent } \\
\text { cotton \&1 drop of } \\
\text { KOH. Dumped basket } \\
\text { contents into tubes \& } \\
\text { placed in water. } \\
\text { Timed } 5 \text { minute } \\
\text { Repeated for cold } \\
\text { room }\end{array}$ & $\begin{array}{l}\text { Measured cell } \\
\text { respiration between } \\
\text { germinating and } \\
\text { nongerminating peas } \\
\text { with a negative } \\
\text { control of glass } \\
\text { beads }\end{array}$ & $\begin{array}{l}\text { We made } 3 \text { different } \\
\text { respirometers, filled } \\
\text { them with germinating } \\
\text { peas, nongerminating } \\
\text { peas and glass beads. } \\
\text { Made sure volume of } \\
\text { gas inside was same } \\
\text { through water } \\
\text { displacement. Put } \\
\text { respirometers in tubs o } \\
\text { cold water \& added } \\
\text { color to tip of pipette } \\
\text { then every } 5 \text { minutes } \\
\text { read volume inside of } \\
\text { pipette. }\end{array}$ \\
\hline $\begin{array}{l}\text { What is } \\
\text { your } \\
\text { opinion } \\
\text { of this } \\
\text { lab? }\end{array}$ & $\begin{array}{l}\text { I liked it a lot, cool, new } \\
\text { technology, something our } \\
\text { generation would do, more } \\
\text { efficient }\end{array}$ & $\begin{array}{l}\text { Would have gotten } \\
\text { better understanding } \\
\text { if I did a wet lab. Easy } \\
\text { to reset mistakes so it } \\
\text { didn't register since I } \\
\text { wasn't actually doing } \\
\text { a wet lab. }\end{array}$ & $\begin{array}{l}\text { Overall pretty cool, } \\
\text { definitely lots of } \\
\text { equipment failure } \\
\text { errors (leaking } \\
\text { pipettes). Find } \\
\text { groups that are } \\
\text { already picked easier } \\
\text { to do than } \\
\text { finding/choosing } \\
\text { partners }\end{array}$ & $\begin{array}{l}\text { Thought it was } \\
\text { interesting but } \\
\text { concepts were } \\
\text { difficult until we } \\
\text { debriefed the next } \\
\text { day. }\end{array}$ \\
\hline $\begin{array}{l}\text { What did } \\
\text { you learn } \\
\text { from this } \\
\text { activity? }\end{array}$ & $\begin{array}{l}\text { I learned a lot more about } \\
\text { cell respiration - easier to } \\
\text { compare my data with } \\
\text { others, saw the difference } \\
\text { between germinated and } \\
\text { non-germinated peas } \\
\text { compared to beads }\end{array}$ & $\begin{array}{l}\text { Don't feel I learned } \\
\text { "it" as much as I } \\
\text { wanted to (It = the } \\
\text { point of the } \\
\text { exercise). The names } \\
\text { of the tools used. } \\
\text { Found experience to } \\
\text { be superficial, not in- } \\
\text { depth. }\end{array}$ & $\begin{array}{l}\text { Not much Electronic } \\
\text { labs get done faster } \\
\text { but wet labs require } \\
\text { new ways to pass the } \\
\text { time while waiting } \\
\text { for results so talking } \\
\text { with a partner helps }\end{array}$ & $\begin{array}{l}\text { That respiration at } \\
\text { colder temperatures } \\
\text { goes slower. } \\
\text { Controlling different } \\
\text { variables, didn't } \\
\text { know you could do } \\
\text { that especially using } \\
\text { the water to control } \\
\text { pressure and } \\
\text { equalizing the } \\
\text { volume before we } \\
\text { started }\end{array}$ \\
\hline $\begin{array}{l}\text { Why do } \\
\text { you think } \\
\text { I } \\
\text { included } \\
\text { this lab } \\
\text { in the gas } \\
\text { exchange } \\
\text { unit? }\end{array}$ & $\begin{array}{l}\text { Demonstrate cell } \\
\text { respiration, a different form } \\
\text { of lab, easier than going to } \\
\text { lab, made it easier for } \\
\text { everyone to get their own } \\
\text { data and not have to share }\end{array}$ & $\begin{array}{l}\text { Cell respiration but } \\
\text { can't recall what lab } \\
\text { was supposed to show } \\
\text { about cell respiration. }\end{array}$ & $\begin{array}{l}\text { Gave the following } \\
\text { Ben Franklin quote } \\
\text { as response: "Tell } \\
\text { me and I will forget, } \\
\text { show me I will learn } \\
\text { and involve me and I } \\
\text { will remember how } \\
\text { it works". }\end{array}$ & $\begin{array}{l}\text { So we can see up } \\
\text { close and have } \\
\text { hands-on experience } \\
\text { with cell respiration }\end{array}$ \\
\hline
\end{tabular}


The photosynthesis lab was conducted on 11/17/2011. Class A performed this lab as a virtual simulation and Classes $\mathrm{B}$ and $\mathrm{C}$ completed this activity in a traditional lab setting. This lab required much less time to set up and run than the cell respiration lab so interviews were conducted privately in class after the students had finished the lab. Since this lab was fairly simple and used mainly as a means of illustrating the relationship between light intensity and oxygen production, there was no formal debriefing. Instead, we held a question and answer session the next day to specifically address any areas of confusion. 


\section{Table 13. Photosynthesis Lab Activity Student Interview Responses}

\begin{tabular}{|c|c|c|c|c|}
\hline \multirow[b]{3}{*}{$\begin{array}{l}\text { Interview } \\
\text { Question }\end{array}$} & \multicolumn{2}{|c|}{ Virtual Photosynthesis Lab } & \multicolumn{2}{|c|}{ Traditional Photosynthesis Wet Lab } \\
\hline & \multicolumn{2}{|c|}{ (simple simulation) } & \multirow[b]{2}{*}{$\begin{array}{c}\text { Student } \mathrm{A}-\text { low } \\
\text { level }\end{array}$} & \multirow[b]{2}{*}{$\begin{array}{c}\text { Student B - high } \\
\text { level }\end{array}$} \\
\hline & $\begin{array}{c}\text { Student A - } \\
\text { low level }\end{array}$ & $\begin{array}{c}\text { Student B - high } \\
\text { level }\end{array}$ & & \\
\hline $\begin{array}{l}\text { Describe } \\
\text { what you } \\
\text { did during } \\
\text { this lab }\end{array}$ & $\begin{array}{l}\text { Don't really } \\
\text { know. } \\
\text { Guess we tested } \\
\text { the.... I don't } \\
\text { know }\end{array}$ & $\begin{array}{l}\text { I just kind of did } \\
\text { what the } \\
\text { instructions said } \\
\text { and I had to redo } \\
\text { it. }\end{array}$ & $\begin{array}{l}\text { Get a plant and } \\
\text { put in tube and } \\
\text { add baking soda. } \\
\text { Get } 2 \text { lights and } \\
\text { put plants in front } \\
\text { of lights and time } \\
\text { the number of } \\
\text { bubbles coming } \\
\text { from cut end. }\end{array}$ & $\begin{array}{l}\text { Took Elodea } \\
\text { plants and put } \\
\text { them in water and } \\
\text { baking soda and } \\
\text { moved light } \\
\text { different distances } \\
\text { to see if distance } \\
\text { affects rate of } \\
\text { oxygen } \\
\text { production. }\end{array}$ \\
\hline $\begin{array}{l}\text { What is } \\
\text { your } \\
\text { opinion of } \\
\text { this lab? }\end{array}$ & $\begin{array}{l}\text { It was fun but } \\
\text { like kind of } \\
\text { really easy } \\
\text { when you } \\
\text { started reading }\end{array}$ & $\begin{array}{l}\text { Did not require a } \\
\text { lot of work and if } \\
\text { something went } \\
\text { wrong, I would } \\
\text { not have had to } \\
\text { fix it because it } \\
\text { automatically was } \\
\text { fixed }\end{array}$ & $\begin{array}{l}\text { Did not like it } \\
\text { because it took a } \\
\text { long time and was } \\
\text { hard to find the } \\
\text { bubbles. Would } \\
\text { have been easier } \\
\text { if we got a better } \\
\text { plant sooner. }\end{array}$ & $\begin{array}{l}\text { Thought it was } \\
\text { interesting and } \\
\text { loved it. Got a } \\
\text { visual real sense } \\
\text { of what happens. }\end{array}$ \\
\hline $\begin{array}{l}\text { What did } \\
\text { you learn } \\
\text { from this } \\
\text { activity? }\end{array}$ & $\begin{array}{l}\text { Honestly not } \\
\text { really because } \\
\text { basically on a } \\
\text { computer they } \\
\text { were doing } \\
\text { steps for you - I } \\
\text { learned how to } \\
\text { do a lab on a } \\
\text { computer }\end{array}$ & $\begin{array}{l}\text { I learned ....I } \\
\text { didn't really learn } \\
\text { a whole lot. Light } \\
\text { affects } \\
\text { photosynthesis } \\
\text { but I already } \\
\text { knew that. }\end{array}$ & $\begin{array}{l}\text { About the } \\
\text { photosynthesis is } \\
\text { how the plants } \\
\text { produce bubbles } \\
\text { in the water. } \\
\text { How to be patient. } \\
\text { I have trouble } \\
\text { being patient for } \\
\text { things like this. }\end{array}$ & $\begin{array}{l}\text { Learned that } \\
\text { different distances } \\
\text { affect rates and } \\
\text { types of light also } \\
\text { had an affect. } \\
\text { Depends on } \\
\text { wavelength. LED } \\
\text { light was stronger } \\
\text { than microscope } \\
\text { light. }\end{array}$ \\
\hline $\begin{array}{l}\text { Why do you } \\
\text { think I } \\
\text { included } \\
\text { this lab in } \\
\text { the gas } \\
\text { exchange } \\
\text { unit? }\end{array}$ & $\begin{array}{l}\text { To see how } \\
\text { working on a } \\
\text { lab on the } \\
\text { computer } \\
\text { works. To see } \\
\text { how the.... I } \\
\text { don't know. }\end{array}$ & $\begin{array}{l}\text { Had to do with } \\
\text { what we are } \\
\text { learning about, } \\
\text { what affects } \\
\text { photosynthesis }\end{array}$ & $\begin{array}{l}\text { So we can know } \\
\text { what } \\
\text { photosynthesis } \\
\text { was. }\end{array}$ & $\begin{array}{l}\text { Something } \\
\text { teacher wanted } \\
\text { students to see } \\
\text {....(oxygen being } \\
\text { produced) and } \\
\text { active } \\
\text { photosynthesis }\end{array}$ \\
\hline
\end{tabular}


Interview topics covered lab purpose, procedure, concepts, transferability of concepts and student assessment of activity. The student responses to the virtual labs tended to be vaguer than their responses to the wet lab. The students who completed the simple photosynthesis simulation had the most difficulty articulating what they had done or why. Both the high level and the low level students discussed following directions and learning how to "do a lab on a computer". Neither of the students who did the virtual lab could describe what they learned. Nor could either of those students answer the transferability question "Suppose you were given a different species of aquatic plant, how would you test if it responds to light the same way as elodea?" (Appendix B). The students who performed the same activity as a wet lab did a better job of describing what they did and what they learned. The higher level students were able to not only articulate that different distances affected the rate of photosynthesis but also recognized that the wavelength of light impacted the photosynthetic rate as well (Table 13).

\section{Whole Class Debriefing Results}

The last form of qualitative assessment I used was a whole class discussion after the unit was completed. I wanted to get a sense of whether or not the interview sample responses represented the overall student opinions. I spent approximately 20 minutes in each class listening to students debate the pros and cons of using computer simulations to replace traditional wet labs. The highlights of the pros and cons that students developed are in Table 14. Many of 
the criticisms that students articulated are the same pros and cons that multiple studies have corroborated including the time, material and cost advantage and the disadvantages associated with the dependence on the strength of the simulation designer, lack of problem solving experience and solitary aspect of many simulations (Triona \& Klahr, 2004; Größler, 2004; Zumbach, Schmitt, Reimann \& Starkloff, 2006; Wekesa, Kiboss \& Ndirangu, 2006). 
Table 14. Highlights of Student-Developed List of Pros and Cons of

Virtual Simulations and Wet Labs

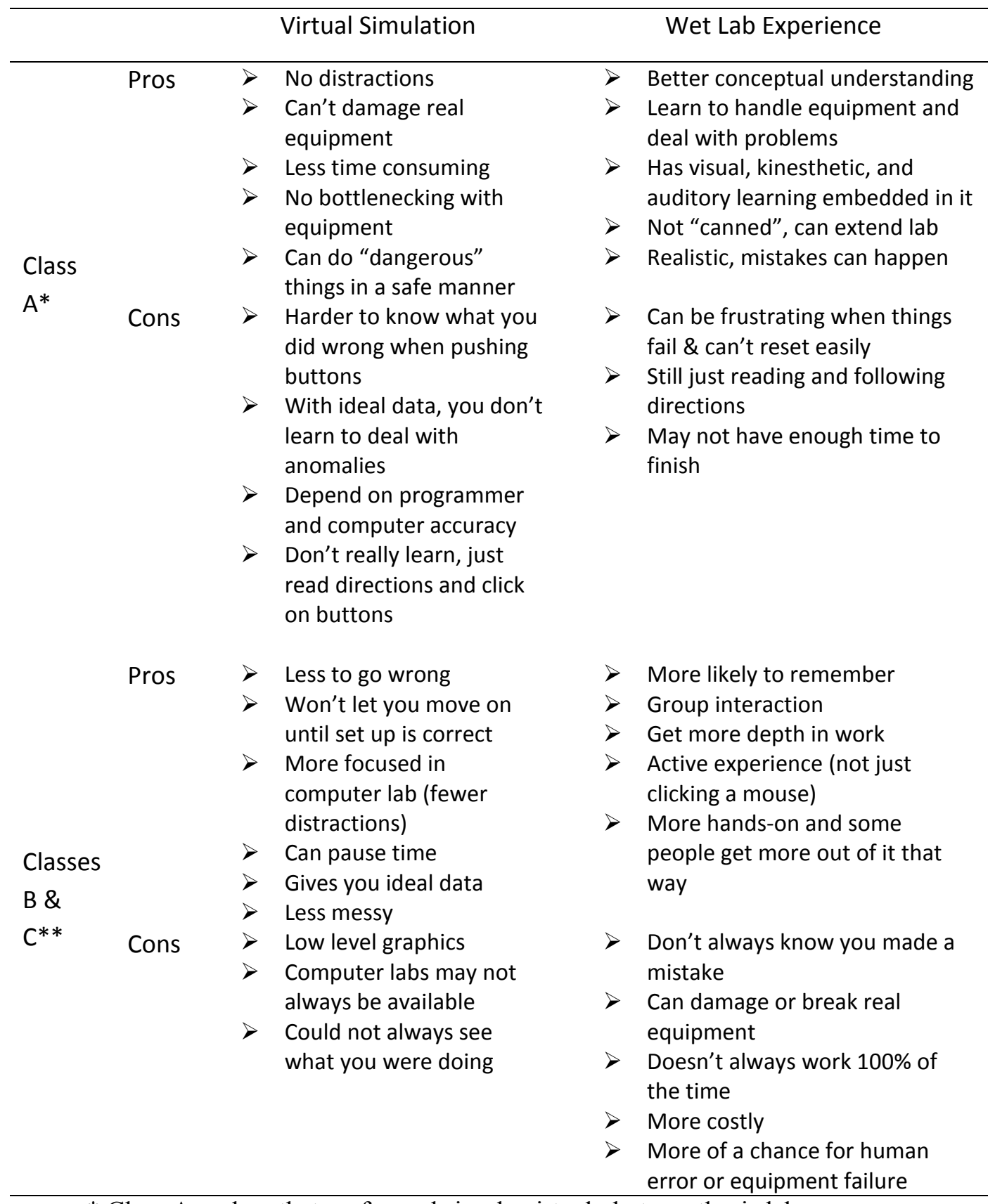

* Class A = class that performed simple virtual photosynthesis lab

$* *$ Classes B \& C = classes that performed complex virtual cell respiration lab 


\section{Chapter 5 - Conclusion}

The goal of this research project was to evaluate the use of computer simulations to replace traditional wet labs as a means to promote concept mastery. Prior to implementing this study, I had anecdotal evidence from students indicating that they preferred to work on virtual simulations and that they learned more from them. Since using a computer lab is much easier to for an instructor, I wanted to evaluate these claims.

Ideally I would have had one treatment where students only completed virtual simulations and another where students only completed wet labs. Unfortunately wet lab access and supplies, time, and computer lab constraints prevented me from doing so. Instead, one class completed a simple virtual lab on one topic while the other classes did the same activity in the lab. Then they reversed roles and the first class completed a more complex wet lab while the other classes completed the same activity on the computer. This format allowed me to compare the use of more and less complex simulations. Since each topic was addressed by a different lab activity and assessed by different item numbers on the concept inventory pre and posttest, I was able to separate the results and evaluate the effectiveness of the different types of simulations. 


\section{Analysis of Student Results on the Concept Inventory Pre and Post}

\section{Tests}

Both treatments showed composite gains on the concept inventory between the pre and post-tests. Class A, the class which completed the simple computer simulation, had a slightly lower gain overall with a composite gain of 9.17 and an effect size of 0.39 (Table 2) compared to Classes B \& C (complex computer simulation group) which had a composite gain of 10.14 and an effect size of 0.52 (Table 3$)$

According to Hattie (2009) and Coe (2002), it is more important to use the effect size as an indicator of intervention effectiveness rather than simply looking at the average gain. Based on Hattie's (2009) barometer, the classes who performed wet labs had an average effect size of 0.50 which is in the range of highly effective intervention strategies. In contrast, the average effect size for the virtual simulations was 0.32 which is still effective but less effective at promoting concept mastery than performing the wet lab.

The general trend showed that the students who performed the virtual experiments in cell respiration or photosynthesis posted lower gains on the posttest on items covering the concepts for the lab they completed as a simulation than the students who performed the wet lab in lieu of the simulation (Tables 4 and 5). For each lab experience, I did the same amount of debriefing regardless if the students completed the activity as a simulation or a wet lab. Since all other factors were the same between treatments, the results suggest that actually working on an activity in a wet lab seems to promote conceptual understanding. This might be partly attributable to the time spent in the lab as well and the 
amount of collaboration among students. The average time the students spent on simulations was approximately 30 minutes. This activity tended to be solitary and the room was almost completely quiet while students were completing the simulation. In the wet lab, students were required to work in assigned groups and the activities lasted from approximately 45 minutes for the photosynthesis lab to 85 minutes for the cell respiration lab. They continually talked to each other during the experience as they tried to ensure they were doing the activity correctly. I heard several students trying to explain the procedure and concepts to peers in their groups which did not happen at all in the computer lab even though there was no injunction against talking.

\section{Analysis of Motivation Inventory Results}

Students completed a motivation inventory prior to beginning the unit on photosynthesis and cell respiration. At the time the initial survey was administered, students had already completed several wet labs so their attitudes were shaped by the lab experiences in my classes and any other lab activities they performed in their prior school setting. Both treatments posted almost identical pre-lab motivation survey results on the items that specifically addressed the traditional wet lab experience on both the pre and post surveys. Class A had a mean response of 5.20 on the 7 point scale and Classes B \& C posted a 5.22 mean response. When responding to the same statements after the gas exchange unit, the mean response decreased slightly for both groups. Class A dropped to a 4.82 mean response and a -0.15 effect size while Classes B \& C dropped to a 5.10 mean response and a -0.04 effect size (Table 6). However, the decline in the 
motivation responses to the traditional lab may partly be attributable to the lab topic. Cell respiration and photosynthesis are fairly abstract compared to some of the other topics covered in the class.

The motivation post-survey was modified to differentiate between the wet lab and simulation experience. Because of time constraints, I kept the number of items the same but modified two out of the four questions addressing each motivation factor from Deci and Ryan's inventory template (2005) included in the survey; interest/enjoyment, perceived competence, effort and importance, pressure and tension, and value and usefulness. When the post-test results were analyzed for the differences in motivation for wet labs compared to simulations, some general trends began to emerge. Class A (simple virtual experience) consistently rated both the real and virtual experiences lower than Classes B \& C. Both Class A and Classes B \& C consistently ranked real labs higher than virtual experiences. It may be that Class A became frustrated during the cell respiration lab when they experienced equipment failures and data that were not "perfect".

After completing the photosynthesis and cell respiration activities, there was not a large discrepancy in the responses to traditional labs compared to computer labs. It may be that the two week time period for this study was insufficient for students to develop a strong preference for computer simulations or traditional labs. Nonetheless, the factor that showed the most discrepancy between the wet lab and simulation experience was the enjoyment factor. Despite the anecdotal evidence provided by students prior to this research project that they preferred completing investigations as simulations, both treatments ranked wet labs much higher on the enjoyment factor. Class A (simple virtual lab) posted a 
mean average of 4.64 for wet labs compared to a 3.50 mean for simulations. The difference was very similar for Classes B \& C (complex virtual lab). They posted a mean average of 5.15 for wet labs compared to a 3.99 mean for simulations (Table 7). This agrees with the classroom observations I made during the study. Students in the wet lab were more animated and involved than those who completed the same activity on the computer.

\section{Qualitative Evidence of Student Understanding and Interest}

I took notes of student behavior and activity during the wet labs and the simulations. During the computer based simulations, I overheard mainly procedural comments like "Why do we have to reset after every time we mess up?" or "I'm in the next room, I made it past the first room". These comments indicated that students perceived the activity more as a check off list or game rather than a simulation designed to illustrate a concept. However, there were some advantages to simulations that I noted as I watched students work. First, all of the students were actively working unlike the wet lab where inevitably one or two students out of the group of three performed more of the work. The computer simulation also yielded almost perfect results every time so students saw what the data were supposed to look like in a perfectly controlled environment. While the simulation did guide students through the process of the activity and yielded perfect data, it did not give them any practice in handling the unexpected.

Some of the comments I overheard in the wet lab included, "Why is my glass bead respirometer moving more than the one with the germinating peas?" or "My data is flawed, I wonder why?" Students did have faulty data and 
problematic equipment but they also had a chance to problem solve and attempt to correct or explain mistakes. This gave them a much better idea of the nature of science. All too often, students leave science classrooms with the impression that scientists wear lab coats, work in pristine labs and never make mistakes, when nothing could be farther from the truth.

\section{Student Interview Implications and Whole Class Comparison of Simulations and Wet Labs}

In general, the interview responses for the more complex lab experience were more detailed. Both the virtual and wet lab students were able to describe the procedure for what they had done. The virtual experience students still had a hard time explaining what they had learned from the activity. For example, a high level student made the comment that he "found the (virtual) experience to be superficial, not in-depth" while the high level wet lab experience student discussed very specific learning outcomes (Table 12). The wet lab students were also able to transfer their learning to a new situation better than the simulation students.

The whole class debriefing sessions echoed the student interview responses. The students who completed the on-line activity needed more explanation and clarification of what they had done and its implications that the wet lab students. Part of the difficulty for the computer-activity students was understanding that the lab was based on real materials. The graphics in the computer simulations were cartoonish and often left students confused about what 
they were seeing. I brought a cell respiration lab set-up to the class that completed the activity on-line to help them visualize the materials. Without that opportunity to see the material, many of the students did not realize that the germinating peas were alive and actively growing.

\section{Problems, Improvements and Future Studies}

The main problem that I faced during this study was logistics. Originally I planned to have one treatment of students who were only completing traditional wet labs and another treatment of students that completed their lab work exclusively as simulations. However, when the other teacher in our science department needed to take a leave of absence, the scheduling of computer labs and wet labs became more of a challenge. This required me to change my focus to compare the use of complex and simple simulations on conceptual understanding for more narrow topics.

Time problems also affected the administration of the motivation survey post-test. It would have been better to administer the exact same survey as a pre and post-test. I did not include items on the original motivation pre-survey regarding simulations because students had not been exposed to simulations prior to the gas exchange unit. This limited my ability to calculate an effect size for items specifically addressing simulations since I did not have the pre-survey standard deviation needed for the calculation. Instead I was forced to use the mean response difference between the items for a particular component of 
motivation as my gauge to compare student response to simulations compared to traditional wet lab experiences.

One variation of this work that I did not have time to study was the effect of completing a simulation as a pre-lab activity in preparation for the wet lab. This might help students familiarize themselves with the procedure of an activity and allow them more time to reflect on the concepts underlying the activity when they complete the wet lab. In fact, several studies discussed the use of simulations as a means of supplementing traditional laboratory work (Scheckler, 2003; Winberg, Anders \& Berg, 2007, Suprasorn et al, 2008). Limniou, Papadopoulos \& Whitehead (2008) found that giving students access to a chemistry simulation prior to actually completing an activity in the laboratory led to more average gain in a concept inventory than students who were only exposed to a traditional pre-lab experience. It would be valuable to study whether or not simulations used as pre-lab activities would be even more effective in biology classes as well.

\section{Educational Implications of Research}

Based on the results from the concept inventory, motivation survey, interviews, class discussions and teacher observations, I believe that computer simulations have some value but do not promote the same skills and concepts as a wet lab experience. Wet labs offer some clear advantages over simulations. Students who performed the wet labs performed much better on the concept inventory assessments for those topics than students who performed similar simulations. Additionally they promote many skills beyond conceptual 
understanding. Students had an opportunity to explore topics in a little more depth and collaborate with other students while performing their investigations. They also were exposed to situations that required problem solving and gave them a glimpse into the nature of science, which is an additive process replete with minor setbacks along the way. Problem solving, collaboration, overcoming equipment failures and correcting design flaws give students an opportunity to experience the true nature of science where progress is not as straightforward as a textbook might indicate.

Nonetheless, there are times when including a simulation has its own value. I found that simulations still correlated with gains in definitional knowledge and propositional knowledge as assessed by the concept inventory but demonstrated smaller gains and effect sizes than wet labs. Additionally during the simulation, all of the students were working instead of a select few in a group so all students were at least exposed to the situations that illustrated classroom concepts.

Scheckler (2003) researched the role of simulations in science classrooms to evaluate whether simulations are more beneficial than traditional lab experiences. She argues that simulations do not offer the level of uncertainty that accompanies a traditional experience nor do they offer a dynamic, human interactive component which is something that my observations and student comments also noted. She found that virtual labs are an excellent tool for concept reinforcement but should be used sparingly. Additionally, based on my experience, simulations should have high level graphics if possible or the 
instructor should bring in examples of lab materials to give students the opportunity to see what they are virtually working with.

There are times when it is much more convenient to use a simulation from the instructor's point of view. Some lab experiences are very time consuming to set up and run in the classroom. In those cases, the instructor needs to assess the value of the experience to determine whether or not the traditional wet lab has enough added value compared to the simulation in order to justify its use. Regardless of the type of experience an instructor wants to include in order to supplement learning, he or she needs to be very clear on the purpose of the activity and communicate that purpose to the students. More importantly, an instructor needs to prepare students adequately for a lab experience prior to conducting it in a wet lab or computer lab and spend enough time debriefing the experience to ensure students understand what they observed and why. This may slow down the curriculum slightly but will allow students to cultivate a deeper understanding of the concepts illustrated by the lab experience.

My initial impetus for completing this project was to evaluate student claims that they preferred doing on-line simulations and that they learned more from them. Based on the results from my study, neither of those claims is supported. Perhaps the students who were advocating for more simulation use were more outspoken than the majority of the students because the results of the motivation survey showed a preference for the wet lab experience. As far as learning more from simulations, that statement was also contradicted by my results. Students who completed wet labs consistently scored higher on the concept inventory for those topics illustrated by the wet lab than the students who 
performed the same activity as a simulation. My last research question was evaluating the differences between simple and complex simulations. I found little difference between the average gains and effect sizes of the simple and the more complex simulations. Class A performed the simple simulation on photosynthesis and posted an average gain of 5.45 with an effect size of 0.39 (Table 4). Classes $\mathrm{B} \& \mathrm{C}$ completed the more complex cell respiration simulation and posted an average gain of 7.60 but only had a 0.25 effect size (Table 5).

Based on my findings, I will recommend that our school maintain our site license for virtual simulations. However, I do not recommend completely replacing all lab experiences with simulations. The traditional lab benefits of collaboration, problem solving and exposure to the nature of science outweigh the simulation benefits of lower cost, space and equipment, and less time. I also think that students benefit from multiple exposures to similar content in different formats. Human beings tend to enjoy some variety in life so offering some content through a variety of methods like wet labs, virtual simulations, traditional lecture, readings, discussion, multimedia presentations or projects will be more likely to pique student interest than relying solely on one method. 


\section{References:}

Amir, R. \& Tamir, P. (1994). In-depth analysis of misconceptions as a basis for developing research-based remedial instruction: The case of photosynthesis. American Biology Teacher, 56(2) 94-100.

Atherton, J.S. (2010, February 10). Teaching and learning; what works and what doesn't. Retrieved 31 May 2011 from http://www.learningandteaching.info/teaching/what_works.htm

Blake, C. \& Scanlon, E. (2007). Reconsidering simulations in science education at a distance: features of effective use. Journal of Computer Assisted Learning, 23, 491-5502.

Brush,T., \& Saye,J. (2001). The use of embedded scaffolds with hypermedia-supported student-centered learning. Journal of Educational Multimedia and Hypermedia, 10(4), 333-356.

Canal, P. (1999). Photosynthesis and 'inverse respiration' in plants: an inevitable misconception? International Journal of Science Education, 21(4), 363-371.

Coe, R. (2002, September). It's the effect size stupid: What effect size is and why it is important. Paper presented at the annual conference of the British Educational Research Association, University of Exeter, England. 
Deci, E. L., \& Ryan, R. M. (2005). Intrinsic motivation inventory (IMI). Retrieved Aug. 20, 2010 from http://www.psych.rochester.edu/SDT/measures/intrins.html.

de Jong,T., \& van Joolingen, W.R. (1998). Scientific discovery learning with computer simulations of conceptual domains. Review of Educational Research, 68, 179-202.

Finkelstein, N.D., Adams, W.K., Keller, C.J., Kohl, P.B., Perkins, K.K., Podolefsky, N.S. \& Reid, S. (2005). When learning about the real world is better done virtually: A study of substituting computer simulations for laboratory equipment. Physical Review Special Topics - Physics Education Research, 1, 010103-1 - 7.

Größler, A. (2004). Don't let history repeat itself - methodological issues concerning the use of simulators in teaching and experimentation. System Dynamics Review, 20, 263-274.

Haslam, F., \& Treagust, D.F. (1987). Diagnosing secondary students' misconceptions of photosynthesis and respiration in plants using a two-tier multiple choice instrument. Journal of Biological Education, 21(3), 203-211.

Hattie, J. (2009). Visible learning; A synthesis of over 800 meta-analyses relating to achievenment. London, UK: Routledge

Hershey, D.R. (2004). Avoid misconceptions when teaching about plants. Retrieved June 7, 2011 from http://www.actionbioscience.orf/education/hershey.html. 
Hoffstein, A. \& Lunetta, V. (2004). The Laboratory in Science Education:

Foundations for the Twenty-First Century. Science Education, 88 (1), 28-

54.

Isaac, S, \& Michael, W. (1995). Handbook in research and evaluation third edition. San Diego, CA: EdITS

Kiboss, J.K. (2002) Impact of a computer-based physics instruction program on pupils' understanding of measurement concepts and methods associated with school science. Journal of Science Education and Technology, 11(2), 193-198.

Kirschner, P., \& Huisman, W. (1998). Dry laboratories in science education: computer-based practical work. International Journal of Science Education, 20(6), 665-682.

Krause, D. (n.d.). Elodea photosynthesis. Retrieved Nov. 17, 2010 from http://eduweblabs.com/

Krause, D. (n.d.). Respiration. Retrieved Nov. 9, 2010 from http://eduweblabs.com/

Limniou, M., Papadopoulos, N. \& Whitehead, C. (2009). Integration of simulation into pre-laboratory chemical course: Computer cluster versus WebCT. Computers and Education, 52, 45-52.

Marbach-Ad, G., McGinnis, R., Dai, A., Schalk, K., \& Benson, S. (2009) Promoting science for all by way of student interest in a transformative undergraduate microbiology laboratory for nonmajors. Journal of Microbiology and Biology Education, 10, 58-67. 
Michigan Department of Education, Office of School Improvement.

(2006). High school science content expectations/ biology

Retrieved Mar, 25, 2011 from

http://www.michigan.gov/documents/Biology_HCSE_168202_7.pdf

Russell ,A., Netherwood, G., and S A Robinson (2004) Photosynthesis In

Silico. Overcoming the Challenges of Photosynthesis Education

Using a Multimedia CD-ROM, Bioscience Education E-journal, 3-

8 retrieved Mar. 2011

http://www.bioscience.heacademy.ac.uk/journal/vol3/beej-3\8.aspx

Schauble,L. Glaser,R., Duschl,R.A., Schulz,S. \& John,J. (1995). Students'

understanding of the objectives and procedures of experimentation

in the science classroom. The Journal of the Learning Sciences, 4, 131-166.

Scheckler, R.K. (2003). Virtual labs: a substitute for traditional labs?

International Journal of Developmental Biology, 47, 231-236.

Suprasorn, S., Suits, J., Jones, L. \& Vibuljan, S. (2008). Impact of a prelaboratory organic-extraction simulation on comprehension and attitudes of undergraduate chemistry students. Chemistry

Education Research and Practice, 9, 169-181.

Swaak,J., van Joolingen, W.R., \& de Jong, T. (1998). Supporting simulation-based learning: The effects of model progression and assignments on definitional and intuitive knowledge. Learning and Instruction, 8, 235-253. 
Triona, L., \& Klahr, D. (2003). Point and click or grab and heft:

comparing the influence of virtual instructional materials on elementary school students' ability to design experiments.

Cognition and Instruction, 21(2), 149-173.

Wekesa, E., Kiboss,J. \& Ndirangu,M. (2006). Improving students' understanding and perception of cell theory in school biology using a computer-based instruction simulation program. Journal of Educational Multimedia and Hypermedia, 15(4), 397-408.

Winberg, T., Anders, C., Berg, \& R. (2007). Students' cognitive focus during a chemistry laboratory exercise: Effects of a computer-simulated prelab. Journal of Research in Science Teaching, 44(8), 1108-1133.

Zumbach,J., Schmitt, S., Reimann, P., \& Starkloff, P. (2006). Learning life sciences: design and development of a virtual molecular biology learning lab. Journal of Computers in Mathematics and Science Teaching, 25 (3), 281-296. 


\section{Appendix A: Informed Consent}




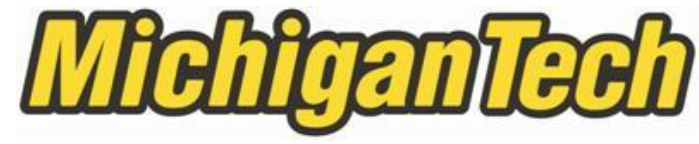

September 8, 2010

Dear Parent or Guardian:

I am Wendy Benya, a master's student of Dr. Brad Baltensperger from the Department of Cognitive and Learning Sciences at Michigan Technological University. I request permission for your student to participate in a research study to be used for my master's thesis. I am conducting a research project comparing computer labs to wet labs to see if they are equally effective in demonstrating biological concepts.

I hope to use what I learn from the study to determine if computer labs are as valuable as wet labs in conveying concepts and teaching basic lab skills.

The study consists of the following activities:

1. Students will perform 2 lab activities concerning photosynthesis and cell respiration. Classes will be randomly assigned to perform the lab on-line or in a traditional wet lab. All students will be exposed to the same lab experience regardless of which group they are in.

2. Students will be asked to take a motivation survey before and after the 2 labs are completed. They will also take a concept pre and post-test and a lab skills pre and post-test.

3. I will ask 2 students from each class for permission to interview them regarding the lab experience. All of their answers will be kept strictly confidential.

The project will be explained in terms that your student can understand, and your student will participate only if he or she is willing to do so.

Only Dr. Baltensperger and I will have access to information from your student. At the conclusion of the study, student responses will be reported as group results only. At the conclusion of the study a summary of group results will be made available to all interested parents. Please indicate at the end of this consent form whether you wish to have these results. If so, please provide your mailing address or email address. 
Participation in this study is voluntary. Your decision whether or not to allow your son or daughter to participate will not affect your son or daughter's grades. Even if you give your permission for your student to participate, your son or daughter is free to refuse to participate. If your student agrees to participate, he or she is free to end participation at any time.

Should you have any questions or desire further information, please feel free to contact
Ms. Wendy Benya
Dr. Brad Baltensperger
Principal Investigator
Department Chair
Early College Alliance
Department of Cognitive and Learning
Sciences
Eastern Michigan University
Michigan Technological University
Ypsilanti, MI 48197
Houghton, MI 49931
$734-487-8154$
$906-487-2460$
wbenya@emich.edu
$\underline{\text { brad@mtu.edu }}$

Keep this letter after completing and returning the signature page to me.

If you have any questions about your rights as a research subject, you may contact the Michigan Technological University Institutional Review Board (IRB) by mail at 1400 Townsend Drive, Houghton, MI 49931, by phone at (908) 487-2902, or by e-mail at jpolzien@mtu.edu.

Sincerely,

\section{Oendy Q Benya}

Department of Cognitive and Learning Sciences 
Please indicate whether or not you wish to allow your son or daughter to participate in this project by checking one of the statements below, signing your name and returning it to me. Sign both copies and keep one for your records.

I do grant permission for my son or daughter to participate in Ms. Wendy Benya's study comparing computer labs to traditional wet labs.

I do not grant permission for my son or daughter to participate in Ms. Wendy Benya's study comparing computer labs to traditional wet labs.

Signature of Parent/Guardian

Printed Name of Child
Printed Parent/Guardian Name

Date

Yes, I would like a copy of the results of this study. My mailing address or email address is below. 


\title{
STUDENT ASSENT TO PARTICIPATE IN RESEARCH
}

\author{
Comparing On-Line Labs To Wet Labs To See If They Are Equally Effective In \\ Teaching Biology Concepts
}

1. My name is Wendy Benya. I am from Michigan Technological University.

2. I am asking you to take part in a research study because I am trying to learn more about whether or not computer lab simulations are as effective as wet labs in demonstrating some of the characteristics and concepts associated with photosynthesis and cell respiration.

3. If you agree to be in this study, I will use the pre-test and post-test data in my project report. I will pre-test and post-test all students on their conceptual understanding as well as lab skills. I will ask a few students if I can interview them to get a better description of what they liked or disliked about either the wet lab or computer lab and about your understanding of the concepts the lab demonstrated.

4. There are no risks associated with participating in this study. All of the information I gather and report will be anonymous. I will not use any student name in my final report. If you choose not to participate in the study, I will exclude your data from the class data.

5. There will be no penalty associated with not participating. Whether or not you participate will not affect your grade in any way. However, if you do choose to participate, I can use your data to determine what kinds of classroom experiences are most effective in helping you learn and understand.

6. If you don't want to be in this study, you don't have to participate. Remember, being in this study is up to you and no one will be upset if you don't want to participate or even if you change your mind later and want to stop.

7. You can ask any questions that you have about the study. If you have a question later that you didn't think of now, you can call me 734-487-8154 or ask me at any point during the study.

9. Signing your name at the bottom means that you agree to be in this study. You and your parents will be given a copy of this form after you have signed $i$

Signature of Student

Printed Name of Student

Date 


\section{Appendix B: Assessment Tools}




\section{Interview Protocol and Questions}

1. Interview start: Explain to student that he or she is going to answer questions based on the lab they just performed. This may be done a day or two after the actual lab because of the school class schedules. Emphasize that this interview is just to gather information and there are no right or wrong responses.

2. Interview Questions: Use the following open-ended questions with the student. If they do not answer right away, stay quiet and allow them time to respond. While it may feel natural to fill silences in the conversation, there is too much of a temptation to ask leading questions and compromise the student response.

- What is the first thing that comes to mind regarding the laboratory exercise that you have just completed?

- Describe what you did during this lab.

- What is your opinion of this lab?

- What did you do to prepare for this lab activity?

- What did you learn from this activity?

- Was there anything that helped you understand?

- Was there anything that made it difficult for you to understand what you were doing and why?

- Why do you think I included this lab in the gas exchange unit?

- Lab specific questions: 
- Photosynthesis: Suppose you were given a different species of aquatic plant, how would you test if it responds to light the same way as elodea?

- Respiration: If you were given a sample of beans that had been found in an old farmhouse, how would you test the effect of seed age on respiration rates?

3. Interpretation: Verify that you understood what the student said during the interview. Clarify any statements that you might misconstrue.

4. Debrief the interview: Thank students for their time and responses and reiterate that any response or quote will be kept strictly anonymous.

Protocol has been modified from:

Winberg, T., Anders, C., Berg, \& R. (2007). Students' cognitive focus during a chemistry laboratory exercise: Effects of a computersimulated prelab. Journal of Research in Science Teaching, 44(8), 1108-1133. 


\section{Photosynthesis \& Respiration in Plants Diagnostic Instrument}

1. What gas is given out in largest amounts by green plants in the presence of sunlight?

\section{A Carbon dioxide}

\section{B Oxygen}

The reason for my answer is because:

1. This gas is given off in the presence of light energy because green plants only respire during the day.

2. This gas is given off by green plants because green plants only photosynthesize and do not respire in the presence of light energy.

3. There is more of this gas produced by the green plant during photosynthesis than is required by the green plant for respiration and other processes, so the excess is given off.

4. This gas is a waste product given off by green plants after they photosynthesize.

5.

2. Which gas is taken in by green plants in large amounts when there is no light energy at all?

A Carbon dioxide gas

B Oxygen gas

The reason for my answer is because:

1. This gas is used in photosynthesis which occurs in green plants all the time.

2 This gas is used in photosynthesis which occurs in green plants when there is no light energy at all.

3. This gas is used in respiration which only occurs in green plants when there is no light energy to photosynthesize.

4. This gas is used in respiration which takes place continuously in green plants.

5 
3. Which gas is given off by green plants in large amounts when there is no light energy at all?
A. Carbon dioxide gas
B. Oxygen gas

The reason for my answer is because:

1. Green plants stop photosynthesizing when there is no light energy at all so they continue to respire and therefore they give off this gas.

2. This gas is given off by the green plant during photosynthesis which takes place when there is no light energy.

3. Since green plants respire only when there is no light energy they give off this gas.

4

4. What gas is taken in by green plants in largest amounts in the presence of light energy?

A. Carbon dioxide gas

B. Oxygen gas

The reason for my answer is because:

1. Green plants make their food from this gas in the presence of light energy.

2. Animals need this gas to respire in the presence of light energy.

3. 
5. Respiration in plants takes place in:

A. the cells of the roots only.

B. every plant cell.

C. the cells of the leaves only.

The reason for my answer is because:

1. All living cells need energy to live.

2. Only leaves have special pores (stomates) to exchange gas.

3. Only roots have small pores to breathe.

4. Only roots need energy to absorb water.

5.

6. Respiration is:

A. A chemical process which occurs in all living cells of plants and animals.

B. A chemical process which occurs in plant cells but not in animal cells.

C. A chemical process which occurs only in animal cells but not in plant cells.

The reason for my answer is because:

1. Only plant cells obtain energy to live in this way.

2. All living cells of plants and animals obtain energy to live through this process.

3. Only animal cells need energy to live as they cannot photosynthesize.

4. 
7. Which of the following is the most accurate statement about respiration in green plants?

A. It is a chemical process by which plants manufacture food from water and carbon dioxide.

B. It is a chemical process in which energy stored in food is released using oxygen.

D. It is the exchange of carbon dioxide and oxygen gases through plant stomates.

E. It is a process that does not take place in green plants when photosynthesis is taking place.

The reason for my answer is because:

1. Green plants never respire they only photosynthesize.

2. Green plants take in carbon dioxide and give off oxygen when they respire.

3. Respiration provides the green plant with energy to live.

4. Respiration only occurs in green plants when there is no light energy.

5.

8. When do green plants respire?

A. Only at night (when there is no light energy).

B. Only during daylight (when there is light energy).

C. All the time (whether there is light energy or when there is no light energy).

The reason for my answer is because:

1. Cells of green plants can photosynthesize during the day when there is light energy and therefore they respire only at night when there is no light energy.

2. Green plants need energy to live and respiration provides energy.

3. Green plants do not respire they only photosynthesize, and photosynthesis provides energy for the plant. 
4.

9. Which of the following equations best represents the process of respiration in plants?
A. Glucose + oxygen $\rightarrow$ energy + carbon dioxide + water.
B. Carbon dioxide + water $\rightarrow$ energy + glucose + oxygen.
C. Carbon dioxide + water $\frac{\text { light energy }}{\text { Chlorophyll }}$ oxygen + glucose.
D. Glucose + oxygen $\rightarrow$ carbon dioxide + water.

The reason for my answer is because:

1. During respiration green plants take in carbon dioxide and water in the presence of light energy to form glucose.

2. Carbon dioxide and water are used by the green plant to produce energy during which time glucose and oxygen waste are produced.

3. During respiration, green plants take in oxygen and give off carbon dioxide and water.

4. During respiration, green plants derive energy from glucose using oxygen.

5.

10. Which of the following equations best represents the overall process of photosynthesis?

A. Glucose + oxygen $\underset{\text { light energy }}{\stackrel{\text { chlorophyll }}{\longrightarrow}}$ carbon dioxide + water

B. Carbon dioxide + water $\underset{\text { chlorophyll }}{\longrightarrow}$ glucose + oxygen light energy

C. Carbon dioxide + water + energy $\rightarrow$ glucose + oxygen 
The reason for my answer is because:

1. The green pigment called chlorophyll combines with the carbon dioxide in the presence of light energy and produces glucose and water.

2. The energy from sunlight is used by plants containing chlorophyll to combine carbon dioxide and water to form glucose and oxygen.

3. Glucose and oxygen are combined in the presence of chlorophyll and light energy to form carbon dioxide and water.

4.

11. Which of the following factors is not important for the process of photosynthesis?
A. Amount of oxygen.
B. Amount of carbon dioxide.
C. Amount of chlorophyll.
D. Amount of light.

The reason for my answer is because:

1. Photosynthesis can take place with no light energy.

2. Non green plants like fungi which do not contain chlorophyll or similar pigments can also photosynthesize.

3. Photosynthesis cannot take place without carbon dioxide.

4. Oxygen is not required for photosynthesis, it is a by-product of photosynthesis.

5. 
12. The most important benefit to green plants when they photosynthesize is:

A. Removal of carbon dioxide from the air.

B. Conversion of light energy to chemical energy.

C. Production of energy.

The reason for my answer is because:

1. Photosynthesis provides energy for plant growth.

2. During photosynthesis, energy from the Sun is converted and stored in glucose molecules.

3. Carbon dioxide is taken in by the leaf through the stomates during photosynthesis.

4. 
13. Which of the following comparisons between the processes of photosynthesis and

respiration in green plants is correct?

\begin{tabular}{|c|l|l|}
\hline $\begin{array}{c}\text { Answer } \\
\text { Letter }\end{array}$ & \multicolumn{1}{|c|}{ Photosynthesis } & \multicolumn{1}{c|}{ Respiration } \\
\hline $\mathbf{A}$ & $\begin{array}{l}\text { Takes place in green plants } \\
\text { only. }\end{array}$ & Takes place in animals only. \\
\hline B & Takes place in all plants. & Takes place only in all animals. \\
\hline C & $\begin{array}{l}\text { Takes place in green plants in } \\
\text { presence of light energy. }\end{array}$ & $\begin{array}{l}\text { Takes place in all plants and in } \\
\text { all } \\
\text { animals at all times. }\end{array}$ \\
\hline D & $\begin{array}{l}\text { Takes place in green plants in } \\
\text { presence of light energy. }\end{array}$ & $\begin{array}{l}\text { Takes place in all plants only } \\
\text { when } \\
\text { there is no light energy and all } \\
\text { the } \\
\text { time in all animals. }\end{array}$ \\
\hline
\end{tabular}

The reason for my answer is because:

1. Green plants photosynthesise and do not respire at all.

2. Green plants photosynthesise during the day and respire at night (when there is no light energy at all).

3. Because respiration is continuous in all living things. Photosynthesis occurs only

when light energy is available.

4. Plants respire when they cannot obtain enough energy from photosynthesis (e.g.at night) and animals respire continuously because they cannot photosynthesize.

5.

Photosynthesis and Respiration In Plants Diagnostic Instrument is used with kind permission from Dr. David Treagust, Deputy Dean of Graduate Studies, Curtin University, Perth, Western Australia 


\section{Science Labs Intrinsic Motivation Inventory Pre-Test}

For each of the following statements, please indicate how true it is for you, using the following scale:

$\begin{array}{ccccccc}1 & 2 & 3 & 4 & 5 & 6 & 7 \\ \text { not at all true } & & & \begin{array}{c}\text { somewhat true } \\ \text { very true }\end{array}\end{array}$

1. I enjoy doing lab activities and experiments.
1
2
3
4
5
6
7

2. Even if I don't do well working on a lab at first, I usually feel competent by the time we are finished.

$\begin{array}{lllllll}1 & 2 & 3 & 4 & 5 & 6 & 7\end{array}$

3. I put a lot of effort into labs.

$\begin{array}{lllllll}1 & 2 & 3 & 4 & 5 & 6 & 7\end{array}$

4. I do not feel nervous doing labs.

$\begin{array}{lllllll}1 & 2 & 3 & 4 & 5 & 6 & 7\end{array}$

5. I believe doing labs and experiments could be of some value to me in this class.

$\begin{array}{lllllll}1 & 2 & 3 & 4 & 5 & 6 & 7\end{array}$

6. Lab activities and experiments are fun to do.
1
2
3
4
$5 \quad 6$
7

7. I am satisfied with how I work on labs and experiments.
12
3
4
5
6
7

8. I usually don't try very hard on labs.
1
2
3
4
5
6
7

9. I feel tense when doing lab activities.
1
2
3
4
$5 \quad 6$
7

10. I think that doing labs and experiments are useful for demonstrating scientific concepts discussed in lecture.
1
2
3
4
5
6
7 
For each of the following statements, please indicate how true it is for you, using the following scale:

$\begin{array}{ccccccc}1 & 2 & 3 & 4 & 5 & 6 & 7 \\ \text { not at all true } & & & \begin{array}{c}4 \\ \text { somewhat true }\end{array} & & & \text { very true }\end{array}$

11. Labs are boring.

$\begin{array}{llllllll}1 & 2 & 3 & 4 & 5 & 6 & 7\end{array}$

12. I feel skilled working in the lab.

$\begin{array}{lllllll}1 & 2 & 3 & 4 & 5 & 6 & 7\end{array}$

13. I try hard on labs and experiments.

$\begin{array}{lllllll}1 & 2 & 3 & 4 & 5 & 6 & 7\end{array}$

14. I feel relaxed doing labs.

$\begin{array}{lllllll}1 & 2 & 3 & 4 & 5 & 6 & 7\end{array}$

15. I think doing lab activities and experiments is important because it can teach me new skills.

$\begin{array}{llllllll}1 & 2 & 3 & 4 & 5 & 6 & 7\end{array}$

16. Labs do not hold my attention at all.

$\begin{array}{lllllll}1 & 2 & 3 & 4 & 5 & 6 & 7\end{array}$

17. In general, I do not do well working on labs.

$\begin{array}{llllllll}1 & 2 & 3 & 4 & 5 & 6 & 7\end{array}$

18. It is important for me to do well on labs.

$\begin{array}{llllllll}1 & 2 & 3 & 4 & 5 & 6 & 7\end{array}$

19. I feel anxious when I work on lab activities or experiments.
1
2
3
4
5
6
7

20. I think that doing labs and experiments can help me to learn to work with others to problem solve.

$\begin{array}{llllllll}1 & 2 & 3 & 4 & 5 & 6 & 7\end{array}$




\section{Science Labs Intrinsic Motivation Inventory Post-Test}

For each of the following statements, please indicate how true it is for you, using the following scale:

$\begin{array}{ccccccc}1 & 2 & 3 & 4 & 5 & 6 & 7 \\ \text { not at all true } & & & \begin{array}{c}4 \\ \text { somewhat true }\end{array} & & & \text { very true }\end{array}$

1. I enjoy doing traditional lab activities and experiments.

$\begin{array}{lllllll}1 & 2 & 3 & 4 & 5 & 6 & 7\end{array}$

2. Even if I don't do well working on a traditional lab at first, I usually feel competent by the time we are finished.
1
2
34
5
$\begin{array}{ll}6 & 7\end{array}$

3. I put a lot of effort into traditional labs.
12
3
4
5
6
7

4. I do not feel nervous doing traditional labs.
1
2
3
4
5
6
7

5. I believe doing traditional labs and experiments could be of some value to me in this class.

$\begin{array}{lllllll}1 & 2 & 3 & 4 & 5 & 6 & 7\end{array}$

6. On-line lab activities and experiments are fun to do.
1
2
3
4
56
7

7. I am satisfied with how I work on on-line labs and experiments.
12
3
4
5
6
7

8. I usually don't try very hard on on-line labs.
1
2
3
4
5
6
7

9. I feel tense when doing on-line lab activities.
1
2
3
4
5
6

10. I think that doing on-line labs and experiments are useful for demonstrating scientific concepts discussed in lecture.
12
3
4
5

6

7 
For each of the following statements, please indicate how true it is for you, using the following scale:

\begin{tabular}{ccccccc}
1 & 2 & 3 & 4 & 5 & 6 & 7 \\
not at all true & & \multicolumn{3}{c}{$\begin{array}{c}\text { somewhat true } \\
\text { very true }\end{array}$} \\
\hline
\end{tabular}

11. Traditional labs are boring.

$\begin{array}{llllllll}1 & 2 & 3 & 4 & 5 & 6 & 7\end{array}$

12. I feel skilled working in the lab.

$\begin{array}{llllllll}1 & 2 & 3 & 4 & 5 & 6 & 7\end{array}$

13. I try hard on traditional labs and experiments.

$\begin{array}{lllllll}1 & 2 & 3 & 4 & 5 & 6 & 7\end{array}$

14. I feel relaxed doing traditional labs.

$\begin{array}{lllllll}1 & 2 & 3 & 4 & 5 & 6 & 7\end{array}$

15. I think doing traditional lab activities and experiments is important because it can teach me new skills.

$\begin{array}{llllllll}1 & 2 & 3 & 4 & 5 & 6 & 7\end{array}$

16. On-line labs do not hold my attention at all.

$\begin{array}{llllllll}1 & 2 & 3 & 4 & 5 & 6 & 7\end{array}$

17. In general, I do not do well working on on-line labs.

$\begin{array}{lllllll}1 & 2 & 3 & 4 & 5 & 6 & 7\end{array}$

18. It is important for me to do well on on-line labs.

$\begin{array}{llllllll}1 & 2 & 3 & 4 & 5 & 6 & 7\end{array}$

19. I feel anxious when I work on on-line lab activities or experiments.
1
2
3
4
56

20. I think that doing on-line labs and experiments can help me to learn to work with others to problem solve.
1
2
3
4
5
6 
Appendix C: Student Lab Handouts 


\section{Elodea \& Photosynthesis Wet Lab}

\section{INTRODUCTION:}

Elodea, also known as Anacharis, is a common freshwater plant used in beginner aquariums. It has leaves that are only a few cells thick which makes it an ideal candidate to use in biological studies of gas exchange. Since oxygen is a byproduct of photosynthesis, you can indirectly measure the rate of photosynthesis by counting the number of bubbles given off by the leaves in a set time period. When the rate of photosynthesis increases, the rate of bubble production also increases. Water temperature, light intensity and the levels of carbon dioxide dissolved in the water will all affect the rate of photosynthesis. During this lab exercise, you will vary the light intensity and light source to observe the affect on the rate of photosynthesis demonstrated by the output of bubbles on Elodea leaves.

Problem: What is the relationship between the distance an Elodea plant is from a light source affect the rate of photosynthesis? Does the type of light source (incandescent or mini-LED) affect the rate of photosynthesis?

\section{Pre-Lab:}

1) According to your text in $\mathrm{Ch} 7$, what is the equation for photosynthesis?

2) Where do plants get the carbon dioxide for this process (describe any and all potential carbon dioxide sources?

3) What plant organelle is the site of photosynthesis?

4) What is the main pigment found in this organelle that absorbs light to power photosynthesis?

5) When plants are underwater and photosynthesizing, what gas could you see bubbling from the plant leaves?

\section{Hypothesis:}




\section{PART A. Equipment Set Up}

A. Get a single, long sprig of Elodea. Remove a few of the lower leaves. Cut the end at an angle and slightly crush.

B. Put a small scoop of sodium bicarbonate (baking soda) into a test tube filled with dechlorinated water to increase the amount of carbon dioxide .

C. Place the Elodea into the test tube with the cut stem end at the top of the test tube. Make sure the cut end is completely covered with water.

\section{PART B. Observation Procedure}

1. Put a light source (incandescent or mini-LED) $5 \mathrm{~cm}$ from the test tube with the Elodea. You may hold the test tube or prop it up in a beaker.

2. Wait one minute for the plant to acclimate.

3. After your 1 minute acclimation time, count the number of bubbles rising from the cut stem of your plant sprig and record in the data table.

4. Repeat two more times at a distance of $10 \mathrm{~cm}$ and $15 \mathrm{~cm}$ respectively.

5. Change your light source and repeat steps 1-4. (If you used the mini-LED's, switch to incandescent)

6. Prepare a graph of your results. The $\mathrm{X}$-axis will be distance from light and the Y-axis will be number of bubbles in 3 minutes.

\section{Data Table:}

\begin{tabular}{|c|c|c|}
\hline Light Type & $\begin{array}{c}\text { Distance from light } \\
\text { source }(\mathbf{c m})\end{array}$ & $\begin{array}{c}\text { \# Bubbles of } \mathbf{O}_{\mathbf{2}} \\
\text { released in } 3 \text { minutes }\end{array}$ \\
\hline Mini LED & $5 \mathrm{~cm}$ & \\
\hline Mini LED & $10 \mathrm{~cm}$ & \\
\hline Mini LED & $15 \mathrm{~cm}$ & \\
\hline Incandescent & $5 \mathrm{~cm}$ & \\
\hline Incandescent & $10 \mathrm{~cm}$ & \\
\hline Incandescent & $15 \mathrm{~cm}$ & \\
& & \\
\hline
\end{tabular}




\section{Graph (bar):}

Title:

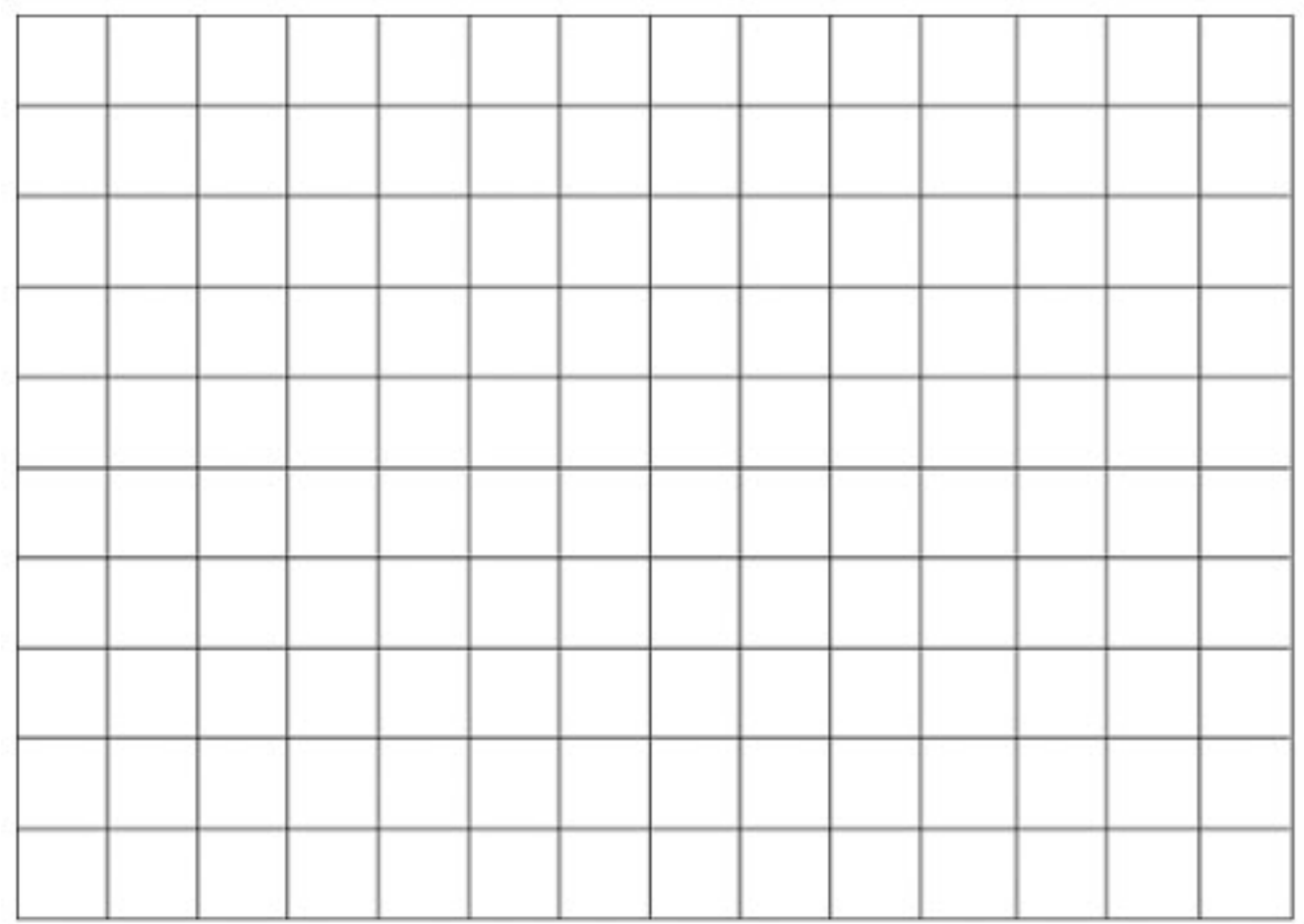

1) Did your results support your initial hypothesis? Explain your answer.

2) What went well with the experiment?

3) What were sources of error or problems during the experiment?

4) How do you explain your results using the concepts of photosynthesis that we have discussed in class?

5) Based on your previous experiences, predict how decreasing the temperature significantly would affect the rate of photosynthesis. Explain your answer. 


\section{On-line Photosynthesis Lab}

\section{PURPOSE:}

To give the student a better understanding of Photosynthesis and the effects of temperature, light intensity and $\mathrm{CO}_{2}$ levels on oxygen production in Elodea. Also to give the student experience in the use and handling of common lab equipment.

\section{INTRODUCTION:}

Elodea, also known as Anacharis, is a common freshwater plant used in beginner aquariums. It has leaves that are only a few cells thick which makes it an ideal candidate to use in biological studies of gas exchange. Since oxygen is a byproduct of photosynthesis, you can indirectly measure the rate of photosynthesis by counting the number of bubbles given off by the leaves in a set time period. When the rate of photosynthesis increases, the rate of bubble production also increases. Water temperature, light intensity and the levels of carbon dioxide dissolved in the water will all affect the rate of photosynthesis. During this lab you will adjust the light levels, temperature of water and levels of $\mathrm{CO}_{2}$ and observe the amount of oxygen bubbles given off by a sample of Elodea.

\section{Pre-Lab Questions:}

1) According to your text in $\mathrm{Ch} 7$, what is the equation for photosynthesis?

2) Where do plants get the carbon dioxide for this process (describe any and all potential carbon dioxide sources?

3) What plant organelle is the site of photosynthesis?

4) What is the main pigment found in this organelle that absorbs light to power photosynthesis?
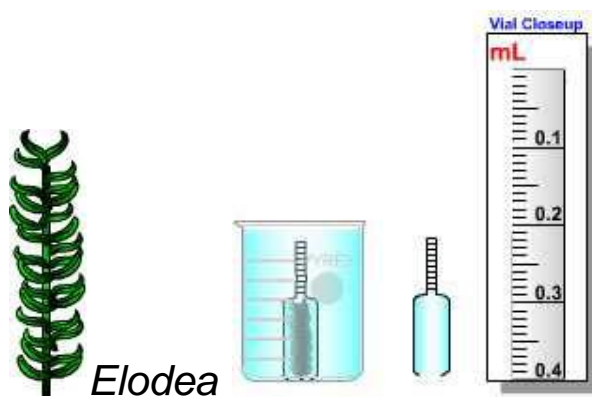

The Elodea will be kept in a water filled beaker, to the left, encased in a glass vial, center. This vial has a graduated tube attached to its top used to measure small amounts of gas. As the oxygen is given off by the plant, the volume can be collected \& observed in this tube. 
1. Complete the light intensity data table below as you change the light distance and temperature in the simulation.

\section{Light Intensity}

\begin{tabular}{|c|c|c|c|c|c|}
\hline $\begin{array}{c}\text { Distance } \\
3 \mathrm{~cm}\end{array}$ & $\begin{array}{c}\text { Volume } \\
\text { (mL) }\end{array}$ & \multicolumn{2}{|c|}{ Temperature } & & \\
\hline $5 \mathrm{~cm}$ & & Temp & Volume (mL) & $\mathrm{NaH}$ & $\mathrm{CO}_{3}$ Added \\
\hline $7 \mathrm{~cm}$ & & $5 \mathrm{C}$ & & Type & Volume $(\mathrm{ml})$ \\
\hline $9 \mathrm{~cm}$ & & $15 \mathrm{C}$ & & $7 \mathrm{~cm}$ & - \\
\hline $11 \mathrm{~cm}$ & & $25 \mathrm{C}$ & 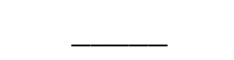 & $25 \mathrm{C}$ & - \\
\hline $13 \mathrm{~cm}$ & & $35 \mathrm{C}$ & - & & \\
\hline $15 \mathrm{~cm}$ & $\overline{ }$ & & & & \\
\hline
\end{tabular}

2. Construct 2 graphs, the one on the left showing the effect of light intensity on the rate of photosynthesis and the one on the right showing the effect of temperature.

Graph Hints:

- Both graphs will share a common $Y$ axis. Label it "volume of oxygen", measured in $\mathrm{mL}$ ranging from 0 to $1.0 \mathrm{~mL}$.

- The $X$ axis for the left graph is measured in $\mathrm{cm}$ ranging from 0 to 17 $\mathrm{cm}$. The right graph is measured in $\mathrm{C}$ ranging from $0-40 \mathrm{C}$.

- Additionally plot the 2 points for the $\mathrm{NaHCO}_{3}$ data. The $7 \mathrm{~cm}$ data will go on the left graph and the $25 \mathrm{C}$ data will go on the right graph.

- If these graph grids are too small for you to use, please use your own graph paper

\section{Conclusion questions:}

1. How does measuring the volume of oxygen in the graduated cylinder measure the rate of photosynthesis?

2. What is the relationship between light intensity and the rate of photosynthesis?

3. What is the relationship between temperature and the rate of photosynthesis?

4. What is the effect of adding additional carbon dioxide to the plant on the rate of photosynthesis?

5. Which variable had the most effect and how do you know? 


\section{On-line lab "Respiration"}

\section{PURPOSE:}

To give the student a better understanding of the relationship between temperature and respiration levels. Also to give the student experience in the use and handling of common lab equipment.

\section{INTRODUCTION:}

As plants undergo respiration a waste product, carbon dioxide, is produced. By measuring the level of this gas given off we can indirectly measure the respiration rate of a common seed such as the pea. In this lab we will measure the respiration rate of peas that have been previously soaked in water (germinated) and dry peas (nongerminated). Readings will be taken at room temperature and at $\mathbf{1 0}$ degrees Celsius.
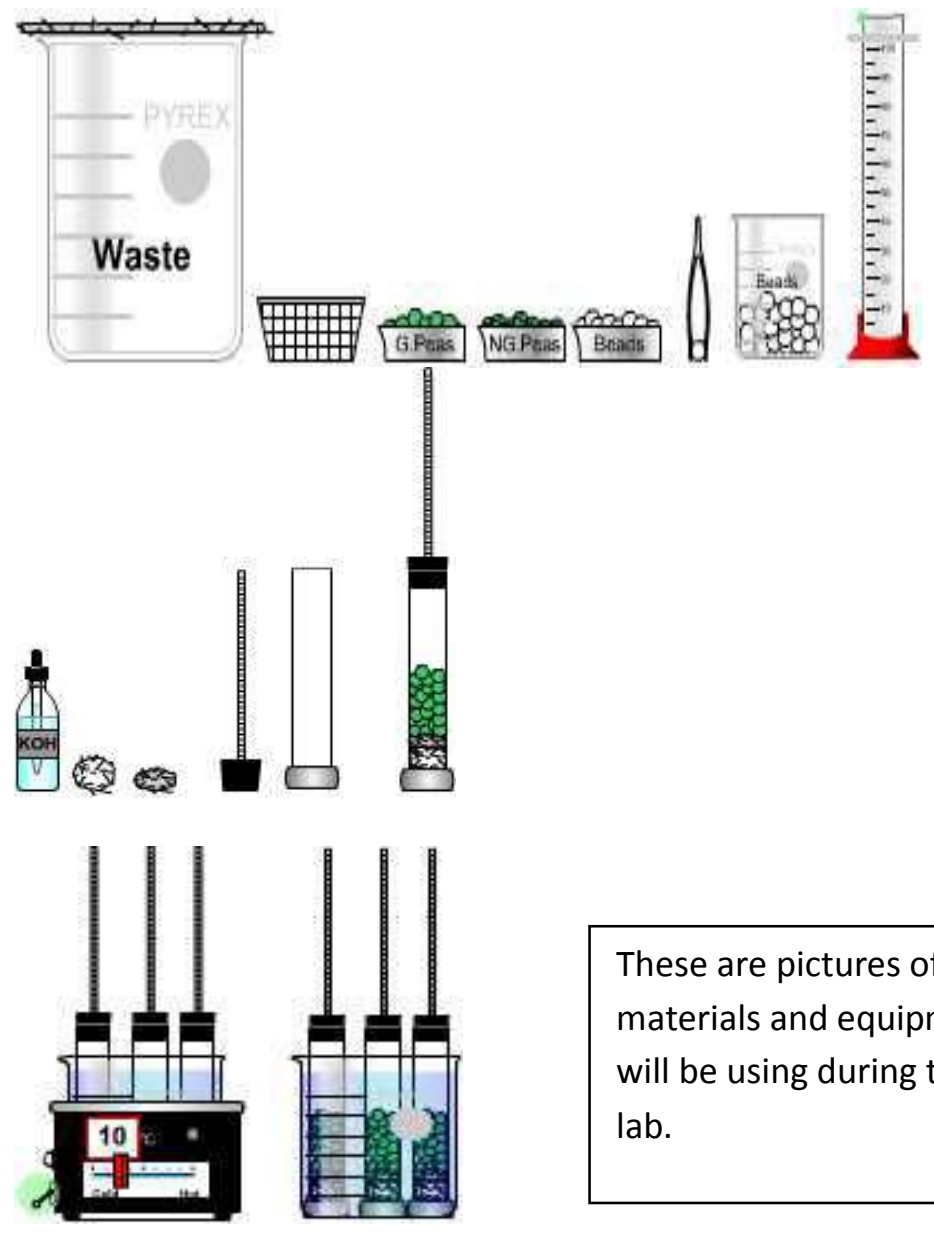

These are pictures of the materials and equipment you will be using during this on-line lab. 


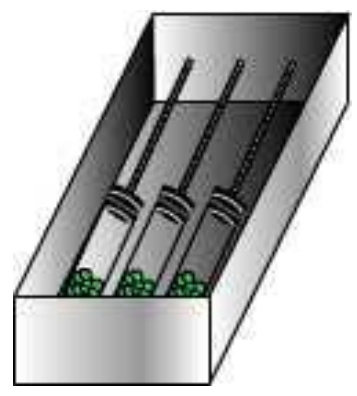

- The peas will be placed in respirometers and then placed in a metal pan after which water is added. Here the respirometers will produce carbon dioxide, which will be indirectly measured. You will read the respirometers by a close-up view of the pipette attached to their stopper. As carbon dioxide is produced and taken from the air in the respirometer, the level of water enters the pipette and can be read.

\section{Analysis and Conclusion Questions:}

1. Plot your data points on the graph on the last page (fill in labels, units and scales), by constructing 4 lines and making a key to indicate what each line is:

1) Germinated/room temp,

2) Germinated/10 C

3) Nongerminated/room temp and

4) Nongerminated/10 C.

Give your graph a title and complete the following information:

a. The independent variable ( $\mathrm{x}$-axis) is

b. The dependent variable ( $y$-axis) is

2. Based on the procedure, write 2 hypotheses that this investigation will test.

1)

2) 
3. During this lab, you measured changes in the volume of the respirometers filled with glass beads, germinating peas, and dormant peas (+ glass beads). The general gas law describes the state of gas under given conditions:

$$
\mathrm{pV}=\mathrm{nRT}
$$

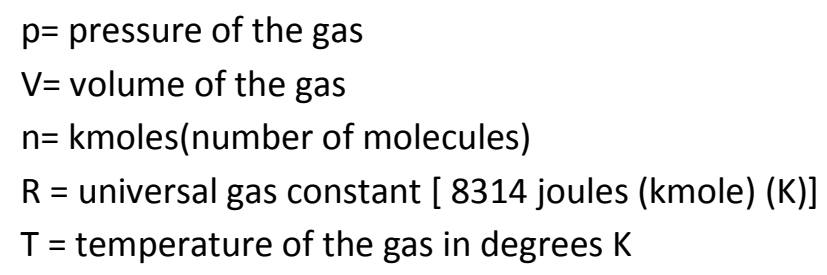

When you solve for volume, the general gas law becomes:

$$
\mathrm{V}=\frac{\mathrm{nRT}}{\mathrm{P}}
$$

Using the general gas law and your experience in this lab, describe the variables that needed to be controlled for your data to be valid. State the controls for each variable and any strategies that were used to correct for the influence of that particular variable. (Keep in mind that in order to be valid, you need to have a clear connection between one variable and the change in respirometer gas volume.)

4. Assuming that all of the controlled (variable) measures worked, what happened to the volume of gas in respirometers 1 , and 2 and why (what happened to the number of molecules of gas and where did these molecules go?)

5. Which of the respirometers $(1,2$, or 3$)$ was your control? Why?

Use your graph and data tables to answer the following questions:

6. What reaction did the wet seeds undergo? (Note that this answer is many reactions all under one general name) What was the water used for? What gas did they use during this reaction?

7. How did the water bath temperature affect the rate of these enzyme-catalyzed reactions? 
8. Using your graph's data points, calculate the rate of oxygen consumption for each treatment:

Remember the rate is: Change between two data points using the Y-axis data

Change between the same two data points using the $\mathrm{X}$-axis data

a. germinating seeds at room temperature

$=$

b. germinating seeds at colder temperature

$=$ $\mathrm{mL} / \mathrm{min}$

c. dormant seeds at room temperature $=$ $\mathrm{mL} / \mathrm{min}$

d. dormant seeds at colder temperature $=$ $\mathrm{mL} / \mathrm{min}$ 


\section{Appendix D: Raw Data}




\begin{tabular}{|c|c|c|c|c|c|c|c|}
\hline \multicolumn{8}{|c|}{$\begin{array}{l}\text { Motivation Inventory Pre-Survey Data } \\
\text { Class A (Simple Virtual Lab/ Complex Wet Lab) }\end{array}$} \\
\hline Statement & $\begin{array}{c}\text { Not At } \\
\text { All True } \\
1\end{array}$ & 2 & 3 & $\begin{array}{l}\text { Somewhat } \\
\text { True } \\
4\end{array}$ & 5 & 6 & $\begin{array}{l}\text { Very } \\
\text { True } \\
7\end{array}$ \\
\hline \multicolumn{8}{|l|}{ Interest/Enjoyment } \\
\hline $\begin{array}{l}\text { I enjoy doing lab } \\
\text { activities and } \\
\text { experiments. }\end{array}$ & 1 & 1 & 1 & 3 & 3 & 11 & 5 \\
\hline $\begin{array}{l}\text { Lab activities and } \\
\text { experiments are fun to } \\
\text { do. }\end{array}$ & 0 & 0 & 2 & 2 & 6 & 6 & 9 \\
\hline $\begin{array}{l}\text { Labs are boring. } \\
\text { (Response is reversed) }\end{array}$ & 0 & 0 & 4 & 0 & 2 & 7 & 10 \\
\hline $\begin{array}{l}\text { Labs do not hold my } \\
\text { attention at all. (Response } \\
\text { is reversed) }\end{array}$ & 0 & 1 & 0 & 1 & 2 & 9 & 10 \\
\hline \multicolumn{8}{|l|}{ Perceived Competence } \\
\hline $\begin{array}{l}\text { Even if I do not do well } \\
\text { working on a lab at first, } \\
\text { I usually feel competent } \\
\text { by time we are finished. }\end{array}$ & 0 & 1 & 4 & 2 & 4 & 12 & 2 \\
\hline $\begin{array}{l}\text { I am satisfied with how I } \\
\text { work on labs and } \\
\text { experiments. }\end{array}$ & 0 & 2 & 1 & 6 & 6 & 5 & 5 \\
\hline $\begin{array}{l}\text { I feel skilled working in } \\
\text { the lab. }\end{array}$ & 0 & 1 & 1 & 8 & 6 & 5 & 2 \\
\hline $\begin{array}{l}\text { In general, I do not do } \\
\text { well working on labs. } \\
\text { (Response is reversed.) }\end{array}$ & 0 & 2 & 0 & 1 & 6 & 5 & 9 \\
\hline \multicolumn{8}{|l|}{ Effort/Importance } \\
\hline $\begin{array}{l}\text { I put a lot of effort into } \\
\text { labs. }\end{array}$ & 0 & 0 & 0 & 5 & 9 & 5 & 6 \\
\hline $\begin{array}{l}\text { I usually don't try very } \\
\text { hard on labs. (Response } \\
\text { is reversed.) }\end{array}$ & 0 & 2 & 0 & 3 & 7 & 6 & 7 \\
\hline I try hard on labs and & 0 & 0 & 0 & 2 & 6 & 8 & 6 \\
\hline
\end{tabular}




\begin{tabular}{|c|c|c|c|c|c|c|c|}
\hline \multicolumn{8}{|c|}{$\begin{array}{l}\text { Motivation Inventory Pre-Survey Data } \\
\text { Class A (Simple Virtual Lab/ Complex Wet Lab) }\end{array}$} \\
\hline experiments. & & & & & & & \\
\hline $\begin{array}{l}\text { It is important for me to } \\
\text { do well on labs. }\end{array}$ & 0 & 1 & 0 & 0 & 4 & 4 & 14 \\
\hline \multicolumn{8}{|l|}{ Pressure/Tension } \\
\hline $\begin{array}{l}\text { I do not feel nervous } \\
\text { doing labs. (Response is } \\
\text { reversed.) }\end{array}$ & 10 & 3 & 5 & 4 & 2 & 0 & 1 \\
\hline $\begin{array}{l}\text { I feel tense when doing } \\
\text { lab activities. }\end{array}$ & 7 & 7 & 3 & 4 & 2 & 2 & 0 \\
\hline $\begin{array}{l}\text { I feel relaxed doing labs. } \\
\text { (Response is reversed.) }\end{array}$ & 1 & 1 & 1 & 6 & 4 & 5 & 5 \\
\hline $\begin{array}{l}\text { I feel anxious when I } \\
\text { work on lab activities or } \\
\text { experiments. }\end{array}$ & 1 & 3 & 3 & 5 & 4 & 4 & 3 \\
\hline \multicolumn{8}{|l|}{ Value/Usefulness } \\
\hline $\begin{array}{l}\text { I believe doing labs and } \\
\text { experiments could be of } \\
\text { some value to me in this } \\
\text { class. }\end{array}$ & 0 & 0 & 0 & 3 & 2 & 11 & 9 \\
\hline $\begin{array}{l}\text { I think that doing labs } \\
\text { and experiments are } \\
\text { useful for demonstrating } \\
\text { scientific concepts } \\
\text { discussed in lecture. }\end{array}$ & 0 & 1 & 0 & 1 & 6 & 8 & 9 \\
\hline $\begin{array}{l}\text { I think doing lab } \\
\text { activities and } \\
\text { experiments is important } \\
\text { because it can teach me } \\
\text { new skills. }\end{array}$ & 0 & 1 & 0 & 0 & 4 & 10 & 7 \\
\hline $\begin{array}{l}\text { I think that doing labs } \\
\text { and experiments can help } \\
\text { me to learn to work with } \\
\text { others to problem solve. }\end{array}$ & 0 & 0 & 1 & 2 & 4 & 9 & 7 \\
\hline
\end{tabular}




\section{Motivation Inventory Pre-Survey Data}

Classes B\& C (Simple Wet Lab/ Complex Virtual Lab)

\begin{tabular}{|c|c|c|c|c|c|c|c|}
\hline Statement & $\begin{array}{c}\text { Not At } \\
\text { All } \\
\text { True } \\
1\end{array}$ & 2 & 3 & $\begin{array}{c}\text { Some } \\
\text { what } \\
\text { True } \\
4\end{array}$ & 5 & 6 & $\begin{array}{c}\text { Very } \\
\text { True } \\
7\end{array}$ \\
\hline \multicolumn{8}{|l|}{ Interest/Enjoyment } \\
\hline $\begin{array}{l}\text { I enjoy doing lab activities } \\
\text { and experiments. }\end{array}$ & 0 & 0 & 2 & 11 & 15 & 8 & 6 \\
\hline $\begin{array}{l}\text { Lab activities and } \\
\text { experiments are fun to do. }\end{array}$ & 1 & 2 & 4 & 8 & 6 & 9 & 12 \\
\hline $\begin{array}{l}\text { Labs are boring. (Response } \\
\text { is reversed) }\end{array}$ & 7 & 12 & 8 & 9 & 3 & 1 & 0 \\
\hline $\begin{array}{l}\text { Labs do not hold my } \\
\text { attention at all. (Response } \\
\text { is reversed) }\end{array}$ & 4 & 13 & 8 & 8 & 3 & 2 & 2 \\
\hline \multicolumn{8}{|l|}{ Perceived Competence } \\
\hline $\begin{array}{l}\text { Even if I do not do well } \\
\text { working on a lab at first, I } \\
\text { usually feel competent by } \\
\text { the time we are finished. }\end{array}$ & 0 & 0 & 4 & 8 & 16 & 10 & 4 \\
\hline $\begin{array}{l}\text { I am satisfied with how I } \\
\text { work on labs and } \\
\text { experiments. }\end{array}$ & 0 & 2 & 2 & 5 & 14 & 11 & 8 \\
\hline $\begin{array}{l}\text { I feel skilled working in the } \\
\text { lab. }\end{array}$ & 0 & 2 & 2 & 11 & 14 & 7 & 3 \\
\hline $\begin{array}{l}\text { In general, I do not do well } \\
\text { working on labs. (Response } \\
\text { is reversed.) }\end{array}$ & 8 & 17 & 4 & 6 & 4 & 1 & 0 \\
\hline \multicolumn{8}{|l|}{ Effort/Importance } \\
\hline $\begin{array}{l}\text { I put a lot of effort into } \\
\text { labs. }\end{array}$ & 0 & 0 & 0 & 9 & 10 & 16 & 7 \\
\hline $\begin{array}{l}\text { I usually don't try very hard } \\
\text { on labs. (Response is } \\
\text { reversed.) }\end{array}$ & 5 & 14 & 5 & 8 & 4 & 0 & 5 \\
\hline
\end{tabular}




\begin{tabular}{|c|c|c|c|c|c|c|c|}
\hline \multicolumn{8}{|c|}{$\begin{array}{l}\text { Motivation Inventory Pre-Survey Data } \\
\text { Classes B\& C (Simple Wet Lab/ Complex Virtual Lab) }\end{array}$} \\
\hline $\begin{array}{l}\text { I try hard on labs and } \\
\text { experiments. }\end{array}$ & 0 & 0 & 1 & 4 & 11 & 14 & 10 \\
\hline $\begin{array}{l}\text { It is important for me to do } \\
\text { well on labs. }\end{array}$ & 0 & 1 & 1 & 6 & 7 & 18 & 7 \\
\hline \multicolumn{8}{|l|}{ Pressure/Tension } \\
\hline $\begin{array}{l}\text { I do not feel nervous doing } \\
\text { labs. (Response is } \\
\text { reversed.) }\end{array}$ & 0 & 2 & 3 & 4 & 8 & 10 & 15 \\
\hline $\begin{array}{l}\text { I feel tense when doing lab } \\
\text { activities. }\end{array}$ & 20 & 10 & 3 & 3 & 3 & 0 & 3 \\
\hline $\begin{array}{l}\text { I feel relaxed doing labs. } \\
\text { (Response is reversed.) }\end{array}$ & 0 & 1 & 5 & 6 & 11 & 12 & 5 \\
\hline $\begin{array}{l}\text { I feel anxious when I work } \\
\text { on lab activities or } \\
\text { experiments. }\end{array}$ & 16 & 9 & 4 & 6 & 2 & 2 & 1 \\
\hline \multicolumn{8}{|l|}{ Value/Usefulness } \\
\hline $\begin{array}{l}\text { I believe doing labs and } \\
\text { experiments could be of } \\
\text { some value to me in this } \\
\text { class. }\end{array}$ & 0 & 1 & 1 & 4 & 9 & 17 & 10 \\
\hline $\begin{array}{l}\text { I think that doing labs and } \\
\text { experiments are useful for } \\
\text { demonstrating scientific } \\
\text { concepts discussed in } \\
\text { lecture. }\end{array}$ & 2 & 1 & 3 & 7 & 9 & 15 & 5 \\
\hline $\begin{array}{l}\text { I think doing lab activities } \\
\text { and experiments is } \\
\text { important because it can } \\
\text { teach me new skills. }\end{array}$ & 0 & 1 & 0 & 7 & 6 & 14 & 12 \\
\hline $\begin{array}{l}\text { I think that doing labs and } \\
\text { experiments can help me to } \\
\text { learn to work with others to } \\
\text { problem solve. }\end{array}$ & 2 & 5 & 2 & 3 & 6 & 20 & 2 \\
\hline
\end{tabular}




\section{Motivation Inventory Post-Survey Data}

Class A (Simple Virtual Lab/ Complex Wet Lab)

\begin{tabular}{|c|c|c|c|c|c|c|c|}
\hline Statement & $\begin{array}{c}\text { Not At } \\
\text { All } \\
\text { True } \\
1\end{array}$ & 2 & 3 & $\begin{array}{c}\text { Some } \\
\text { what } \\
\text { True } \\
4\end{array}$ & 5 & 6 & $\begin{array}{c}\mathrm{Ve} \\
\text { ry } \\
\mathrm{Tr} \\
\text { ue } \\
7\end{array}$ \\
\hline
\end{tabular}

Interest/Enjoyment

\begin{tabular}{|l|r|r|r|r|r|r|r|}
\hline $\begin{array}{l}\text { I enjoy doing traditional lab } \\
\text { activities and experiments. }\end{array}$ & 1 & 1 & 0 & 8 & 4 & 6 & 4 \\
\hline $\begin{array}{l}\text { On-line lab activities and } \\
\text { experiments are fun to do. }\end{array}$ & 0 & 4 & 3 & 3 & 4 & 6 & 4 \\
\hline $\begin{array}{l}\text { Traditional labs are boring. } \\
\text { (Response is reversed) }\end{array}$ & 10 & 5 & 4 & 2 & 2 & 0 & 1 \\
\hline $\begin{array}{l}\text { On-line labs do not hold my } \\
\text { attention at all. (Response is } \\
\text { reversed) }\end{array}$ & 5 & 6 & 5 & 3 & 1 & 3 & 1 \\
\hline
\end{tabular}

Perceived Competence

\begin{tabular}{|c|c|c|c|c|c|c|c|}
\hline $\begin{array}{l}\text { Even if I do not do well working } \\
\text { on a traditional lab at first, I } \\
\text { usually feel competent by the time } \\
\text { we are finished. }\end{array}$ & 0 & 2 & 2 & 2 & 8 & 8 & 2 \\
\hline $\begin{array}{l}\text { I am satisfied with how I work on } \\
\text { on-line labs and experiments. }\end{array}$ & 1 & 0 & 2 & 3 & 8 & 4 & 6 \\
\hline I feel skilled working in the lab. & 1 & 2 & 4 & 9 & 4 & 2 & 2 \\
\hline $\begin{array}{l}\text { In general, I do not do well } \\
\text { working on on-line labs. } \\
\text { (Response is reversed.) }\end{array}$ & 6 & 9 & 4 & 1 & 2 & 0 & 1 \\
\hline \multicolumn{8}{|l|}{ Effort/Importance } \\
\hline $\begin{array}{l}\text { I put a lot of effort into traditional } \\
\text { labs. }\end{array}$ & 0 & 0 & 1 & 3 & 5 & 9 & 6 \\
\hline $\begin{array}{l}\text { I usually don't try very hard on on- } \\
\text { line labs. (Response is reversed.) }\end{array}$ & 5 & 6 & 3 & 2 & 3 & 2 & 2 \\
\hline $\begin{array}{l}\text { I try hard on traditional labs and } \\
\text { experiments. }\end{array}$ & 0 & 0 & 3 & 1 & 8 & 5 & 7 \\
\hline $\begin{array}{l}\text { It is important for me to do well on } \\
\text { on-line labs. }\end{array}$ & 0 & 1 & 2 & 2 & 3 & 4 & 12 \\
\hline
\end{tabular}




\begin{tabular}{|c|c|c|c|c|c|c|c|}
\hline \multicolumn{8}{|c|}{$\begin{array}{l}\text { Motivation Inventory Post-Survey Data } \\
\text { Class A (Simple Virtual Lab/ Complex Wet Lab) }\end{array}$} \\
\hline \multicolumn{8}{|l|}{ Pressure/Tension } \\
\hline $\begin{array}{l}\text { I do not feel nervous doing } \\
\text { traditional labs. (Response is } \\
\text { reversed.) }\end{array}$ & 0 & 2 & 4 & 5 & 2 & 7 & 4 \\
\hline $\begin{array}{l}\text { I feel tense when doing on-line lab } \\
\text { activities. }\end{array}$ & 9 & 10 & 2 & 1 & 1 & 1 & 0 \\
\hline $\begin{array}{l}\text { I feel relaxed doing traditional } \\
\text { labs. (Response is reversed.) }\end{array}$ & 2 & 1 & 7 & 3 & 5 & 1 & 5 \\
\hline $\begin{array}{l}\text { I feel anxious when I work on on- } \\
\text { line lab activities or experiments. }\end{array}$ & 12 & 3 & 3 & 3 & 1 & 1 & 1 \\
\hline \multicolumn{8}{|l|}{ Value/Usefulness } \\
\hline $\begin{array}{l}\text { I believe doing traditional labs } \\
\text { and experiments could be of some } \\
\text { value to me in this class. }\end{array}$ & 0 & 0 & 1 & 3 & 6 & 5 & 9 \\
\hline $\begin{array}{l}\text { I think that doing on-line labs and } \\
\text { experiments are useful for } \\
\text { demonstrating scientific concepts } \\
\text { discussed in lecture. }\end{array}$ & 1 & 2 & 1 & 7 & 2 & 5 & 6 \\
\hline $\begin{array}{l}\text { I think doing traditional lab } \\
\text { activities and experiments is } \\
\text { important because it can teach me } \\
\text { new skills. }\end{array}$ & 1 & 2 & 1 & 7 & 2 & 5 & 6 \\
\hline $\begin{array}{l}\text { I think that doing on-line labs and } \\
\text { experiments can help me to learn to } \\
\text { work with others to problem solve. }\end{array}$ & 4 & 3 & 2 & 7 & 2 & 3 & 3 \\
\hline
\end{tabular}




\section{Motivation Inventory Post-Survey Data}

Classes B\& C (Simple Wet Lab/ Complex Virtual Lab)

\begin{tabular}{|c|c|c|c|c|c|c|c|}
\hline Statement & $\begin{array}{c}\text { Not At } \\
\text { All } \\
\text { True } \\
1\end{array}$ & 2 & 3 & $\begin{array}{c}\text { Some } \\
\text { what } \\
\text { True } \\
4\end{array}$ & 5 & 6 & $\begin{array}{c}\text { Very } \\
\text { True } \\
7\end{array}$ \\
\hline \multicolumn{8}{|l|}{ Interest/Enjoyment } \\
\hline $\begin{array}{l}\text { I enjoy doing traditional lab } \\
\text { activities and experiments. }\end{array}$ & 0 & 0 & 2 & 11 & 15 & 8 & 6 \\
\hline $\begin{array}{l}\text { On-line lab activities and } \\
\text { experiments are fun to do. }\end{array}$ & 1 & 2 & 4 & 8 & 6 & 9 & 12 \\
\hline $\begin{array}{l}\text { Traditional labs are boring. } \\
\text { (Response is reversed) }\end{array}$ & 7 & 12 & 8 & 9 & 3 & 1 & 0 \\
\hline $\begin{array}{l}\text { On-line labs do not hold my } \\
\text { attention at all. (Response is } \\
\text { reversed) }\end{array}$ & 4 & 13 & 8 & 8 & 3 & 2 & 2 \\
\hline
\end{tabular}

\section{Perceived Competence}

\begin{tabular}{|l|r|r|r|r|r|r|r|}
\hline $\begin{array}{l}\text { Even if I do not do well working } \\
\text { on a traditional lab at first, I } \\
\begin{array}{l}\text { usually feel competent by the } \\
\text { time we are finished. }\end{array}\end{array}$ & 0 & 0 & 4 & 8 & 16 & 10 & 4 \\
\hline $\begin{array}{l}\text { I am satisfied with how I work on } \\
\text { on-line labs and experiments. }\end{array}$ & 0 & 2 & 2 & 5 & 14 & 11 & 8 \\
\hline I feel skilled working in the lab. & 0 & 2 & 2 & 11 & 14 & 7 & 3 \\
\hline $\begin{array}{l}\text { In general, I do not do well } \\
\text { working on on-line labs. } \\
\text { (Response is reversed.) }\end{array}$ & 8 & 17 & 4 & 6 & 4 & 1 & 0 \\
\hline
\end{tabular}

Effort/Importance

\begin{tabular}{|l|r|r|r|r|r|r|r|}
\hline $\begin{array}{l}\text { I put a lot of effort into } \\
\text { traditional labs. }\end{array}$ & 0 & 0 & 0 & 9 & 10 & 16 & 7 \\
\hline $\begin{array}{l}\text { I usually don't try very hard on } \\
\text { on-line labs. (Response is } \\
\text { reversed.) }\end{array}$ & 5 & 14 & 5 & 8 & 4 & 0 & 5 \\
\hline $\begin{array}{l}\text { I try hard on traditional labs and } \\
\text { experiments. }\end{array}$ & 0 & 0 & 1 & 4 & 11 & 14 & 10 \\
\hline $\begin{array}{l}\text { It is important for me to do well } \\
\text { on on-line labs. }\end{array}$ & 0 & 1 & 1 & 6 & 7 & 18 & 7 \\
\hline
\end{tabular}




\begin{tabular}{|c|c|c|c|c|c|c|c|}
\hline \multicolumn{8}{|c|}{$\begin{array}{l}\text { Motivation Inventory Post-Survey Data } \\
\text { Classes B\& C (Simple Wet Lab/ Complex Virtual Lab) }\end{array}$} \\
\hline \multicolumn{8}{|l|}{ Pressure/Tension } \\
\hline $\begin{array}{l}\text { I do not feel nervous doing } \\
\text { traditional labs. (Response is } \\
\text { reversed.) }\end{array}$ & 0 & 2 & 3 & 4 & 8 & 10 & 15 \\
\hline $\begin{array}{l}\text { I feel tense when doing on-line } \\
\text { lab activities. }\end{array}$ & 20 & 10 & 3 & 3 & 3 & 0 & 3 \\
\hline $\begin{array}{l}\text { I feel relaxed doing traditional } \\
\text { labs. (Response is reversed.) }\end{array}$ & 0 & 1 & 5 & 6 & 11 & 12 & 5 \\
\hline $\begin{array}{l}\text { I feel anxious when I work on on- } \\
\text { line lab activities or experiments. }\end{array}$ & 16 & 9 & 4 & 6 & 2 & 2 & 1 \\
\hline \multicolumn{8}{|l|}{ Value/Usefulness } \\
\hline $\begin{array}{l}\text { I believe doing traditional labs } \\
\text { and experiments could be of some } \\
\text { value to me in this class. }\end{array}$ & 0 & 1 & 1 & 4 & 9 & 17 & 10 \\
\hline $\begin{array}{l}\text { I think that doing on-line labs and } \\
\text { experiments are useful for } \\
\text { demonstrating scientific concepts } \\
\text { discussed in lecture. }\end{array}$ & 2 & 1 & 3 & 7 & 9 & 15 & 5 \\
\hline $\begin{array}{l}\text { I think doing traditional lab } \\
\text { activities and experiments is } \\
\text { important because it can teach me } \\
\text { new skills. }\end{array}$ & 0 & 1 & 0 & 7 & 6 & 14 & 12 \\
\hline $\begin{array}{l}\text { I think that doing on-line labs and } \\
\text { experiments can help me to learn } \\
\text { to work with others to problem } \\
\text { solve. }\end{array}$ & 2 & 5 & 2 & 3 & 6 & 20 & 2 \\
\hline
\end{tabular}

